\title{
IFAU
}

Institute for Evaluation of Labour

Market and Education Policy

\section{Rising to the occasion? \\ Youth political knowledge and the voting age}

\section{Olof Rosenqvist}


The Institute for Evaluation of Labour Market and Education Policy (IFAU) is a research institute under the Swedish Ministry of Employment, situated in Uppsala. IFAU's objective is to promote, support and carry out scientific evaluations. The assignment includes: the effects of labour market and educational policies, studies of the functioning of the labour market and the labour market effects of social insurance policies. IFAU shall also disseminate its results so that they become accessible to different interested parties in Sweden and abroad.

IFAU also provides funding for research projects within its areas of interest. The deadline for applications is October 1 each year. Since the researchers at IFAU are mainly economists, researchers from other disciplines are encouraged to apply for funding.

IFAU is run by a Director-General. The institute has a scientific council, consisting of a chairman, the Director-General and five other members. Among other things, the scientific council proposes a decision for the allocation of research grants. A reference group including representatives for employer organizations and trade unions, as well as the ministries and authorities concerned is also connected to the institute.

Postal address: P.O. Box 513, 75120 Uppsala

Visiting address: Kyrkogårdsgatan 6, Uppsala

Phone: +4618 4717070

Fax: +4618471 7071

ifau@ifau.uu.se

www.ifau.se

Papers published in the Working Paper Series should, according to the IFAU policy, have been discussed at seminars held at IFAU and at least one other academic forum, and have been read by one external and one internal referee. They need not, however, have undergone the standard scrutiny for publication in a scientific journal. The purpose of the Working Paper Series is to provide a factual basis for public policy and the public policy discussion.

ISSN 1651-1166 


\title{
Rising to the occasion? \\ Youth political knowledge and the voting age $\mathrm{e}^{\mathrm{a}}$
}

\author{
by \\ Olof Rosenqvist ${ }^{\mathrm{b}}$ \\ March 16, 2016
}

\begin{abstract}
Voting is a fundamental human right. Yet, individuals that are younger than 18 do typically not have this right since they are considered uninformed. However, recent evidence tentatively suggests that the political knowledge of youths is endogenous to the voting age. I test for the existence of such dynamic adjustments utilizing voting age discontinuities caused by Swedish laws. I employ a regression discontinuity strategy on Swedish register data to estimate the causal effect of early age voting right on political knowledge around age 18. The results do not support the existence of positive causal effects of early age voting right on political knowledge. Thus, we should not expect that 16-year-olds respond by acquiring more political knowledge if they are given the right to vote. This finding weakens the case for a lowering of the voting age from 18 to 16.
\end{abstract}

Keywords: Voting age, political knowledge, civic interest, tertiary education, regression discontinuity design

JEL-codes: I21, P16, D04, D72, I29

\footnotetext{
a I thank Oskar Nordström Skans, Martin Lundin, Karl-Oskar Lindgren, Lena Hensvik, Erik Lindqvist and audiences at IFAU and SUDSWEC 2015 in Uppsala for helpful comments and suggestions.

${ }^{\mathrm{b}}$ Uppsala University, Economics Department and Institute for Evaluation of Labour Market and Education Policy (IFAU), olof.rosenqvist@nek.uu.se.
} 


\section{Table of contents}

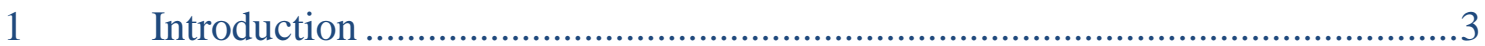

$2 \quad$ Related literature, political knowledge and measurements ................................8

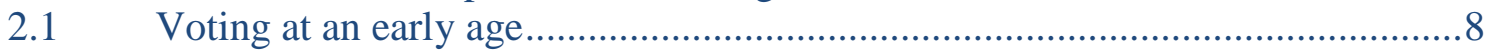

2.2 Political knowledge: Definition, importance and measurement .........................9

2.3 Measures of political knowledge and political interest used in this paper ........10

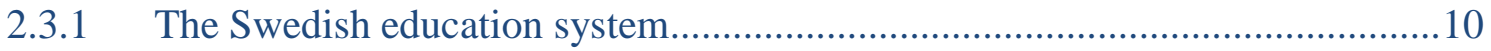

2.3.2 Main measure: high school grade in Social Studies..........................................10

2.3.3 Potential problem with the high school grade in Social Studies .......................11

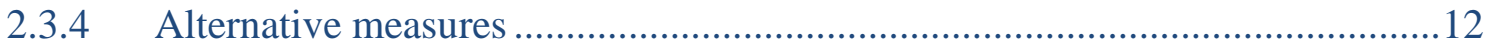

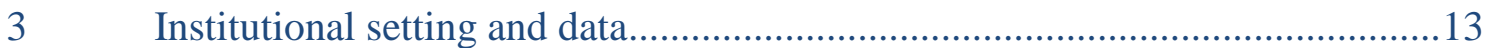

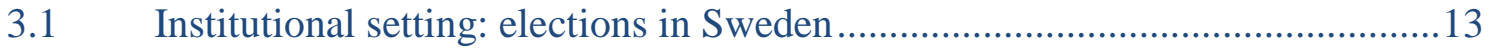

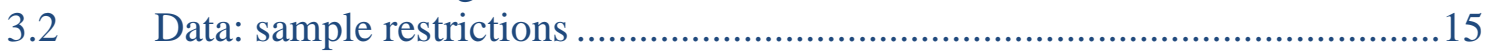

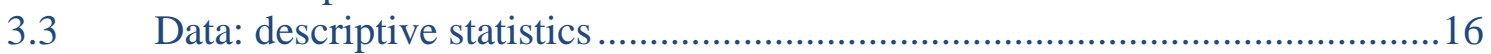

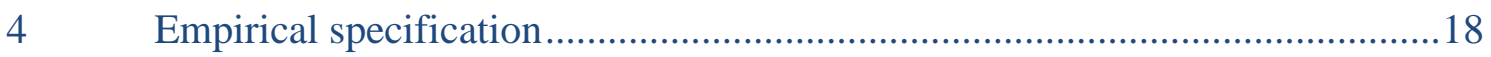

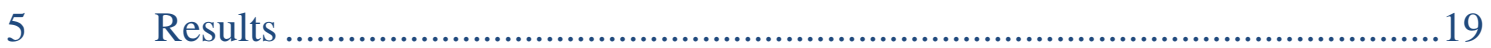

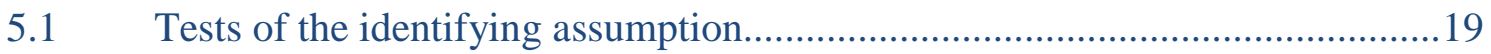

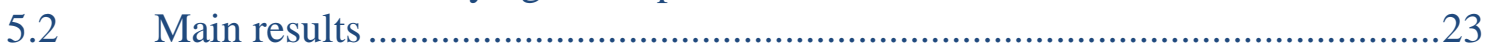

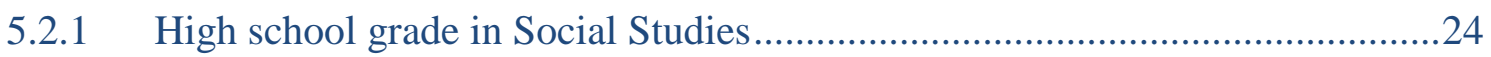

5.2.2 Score on the General Knowledge section of the SweSAT ................................27

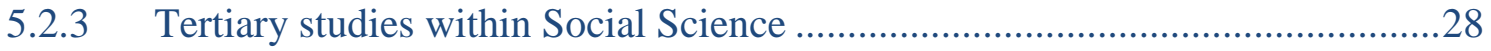

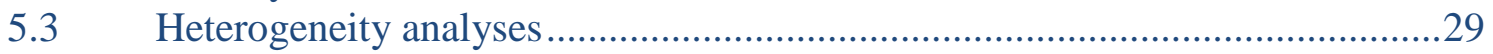

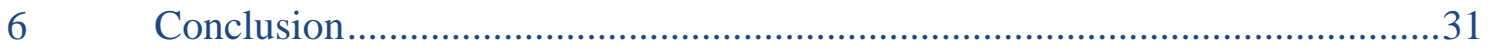

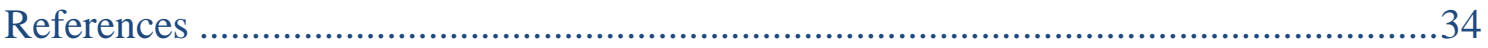

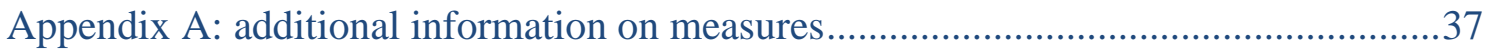

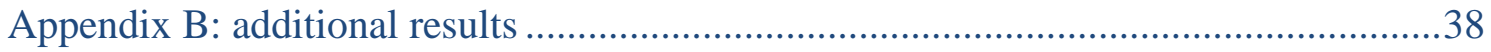




\section{Introduction}

Having the right to vote is a fundamental human right (The United Nations, 1948, art. 21). So why are not all citizens allowed to vote? ${ }^{1}$ The main argument against lowering or abolishing the voting age is that young individuals, according to the proponents of the current voting age, typically lack the appropriate intellectual maturity and political knowledge for voting (see, e.g., Chan and Clayton [2006]). In this paper, motivated by recent evidence, I study if having the right to vote in itself can stimulate the acquirement of political knowledge, i.e. if youths that are given the right to vote rise to the occasion.

Having the right to vote "empowers citizens to influence governmental decisionmaking and to safeguard their other human rights” (Human Rights Advocates [2009], p. 2). Thus, it must be considered a serious violation of the human rights to exclude a section of the population from voting without very strong reasons for doing so. The typical voting age today is 18 meaning that a large share (approx. $25 \%$, [Central Intelligence Agency, 2015]) of the population in most countries lacks the right to vote because they are considered immature in several ways. Can this voting age be justified or should it be lowered? And if it is lowered, how will it affect young individuals that become eligible? While this paper does not give a definite answer to these questions it aims at contributing to the discussion by providing relevant and credible new evidence.

Obviously, this question has been discussed in many countries during the last ten years because there have been several changes of the voting age from 18 to 16 . In 2007, Austria became the first European nation to adopt a voting age of 16 (see Wagner et al. [2012]) and in the Scottish independence referendum in 2014, 16-year-olds were also allowed to vote (UK Government [2015]). Another major example is Argentina where the voting age was lowered to 16 in 2012 (see The Telegraph [2012]).

The experiences from the Scottish referendum have triggered a discussion in the UK whether the voting age should be lowered to 16 in all elections. Alex Salmond, Scotland's first minister and leader of the Scottish Nationalist Party (SNP) at the time of the independence referendum, was impressed by the engagement of the young voters and delivered the following comment in his first statement to the Scottish Parliament after the referendum:

\footnotetext{
${ }^{1}$ Individuals under the age of 18 are typically not allowed to vote. See list of voting ages around the world compiled by the Central Intelligence Agency (2015).
} 
"There is not a shred of evidence for arguing now 16- and 17-year-olds should not be allowed to vote. Their engagement in this debate, this great constitutional debate, was second to none. They proved themselves to be the serious, passionate and committed citizens we always believed they should be. Everyone in this chamber should be proud of this chamber's decision to widen the franchise. There is an overwhelming, indeed an unanswerable, case for giving 16- and 17-year-olds the vote in all future elections in Scotland, indeed across the United Kingdom. All parties in this parliament I think should make a vow to urge Westminster to make this happen in time for next year's general election.” Brooks (2014).

Given this current debate and the ethical dilemma surrounding the existence of a voting age it is of major importance to accumulate information about the political knowledge of, primarily, 16- and 17- year olds in relation to their older fellow citizens. To the best of my knowledge there have been two major contributions to this topic, Chan and Clayton (2006) and Wagner et al. (2012), and they have reached completely different conclusions.

Chan and Clayton (2006) used British survey data from the 1990s and 2001 to study the political interest and knowledge of different age groups. They find a clear age gradient in political maturity with 16- and 17-year-olds at the bottom of the competence scale. Based on this finding they argue that the voting age should not be lowered to 16 since this would lead to negative consequences for the quality of democracy.

Wagner et al. (2012), on the other hand, using Austrian survey data from 2009 reach a contradicting conclusion. Wagner et al. (2012) find that 16-and 17-year-olds are about equally willing to participate in politics and about equally able to make informed voting decision as their somewhat older fellow citizens (18-21 years of age). Particularly, they do not find that the vote choices of 16- and 17-year-olds are worse, in terms of correspondence with preferences, than those of somewhat older age groups. Based on this finding they argue that 16- and 17-year-olds should not be excluded from voting on the grounds of insufficient political knowledge.

Why are the results so different? Wagner et al. (2012) offer a potential explanation related to the different voting laws in UK and Austria. The 16- and 17-year-olds that were surveyed in Chan and Clayton (2006) did not have the right vote while the corresponding group in Wagner et al. (2012) actually did have that right. In fact, Austria 
introduced a voting age of 16 in 2007 and when Wagner et al. (2012) did their survey in May 2009, the 16- and 17-year-olds in the study were very soon about to vote in their first election (European Parliament Election in June 2009). Wagner et al. (2012) argue that citizens that lack the right to vote have very small incentives to get politically knowledgeable while being eligible means that political knowledge actually can be put to use. Thus, according to Wagner et al. (2012), 16- and 17-year-olds in Austria are more politically mature in relation to their somewhat older fellow citizens than their counterparts in UK in part because they have the right to vote. This reasoning suggests the existence of dynamic effects from changing the voting age, where the political maturity of youths endogenously adjusts to the prevailing voting age, i.e. the youths "rise to the occasion".

This idea gets additional support from Hart and Atkins (2011) and Zeglovits and Zandonella (2013). Hart and Atkins (2011) argue that the voting age should be lowered to 16 because there is evidence that indicates that opportunities of political socialization during adolescence lead to a deeper civic commitment in early adulthood. Along a similar line Zeglovits and Zandonella (2013) provide evidence suggesting that the political interest of youths respond to changes in the voting age. ${ }^{2}$ While the hypothesis that youths react to changes in the voting age is intriguing and consistent with the results in Chan and Clayton (2006) and Wagner et al. (2012) it has not been properly evaluated. The diverging results in Chan and Clayton (2006) and Wagner et al. (2012) could potentially also be explained by other cross-country differences between Austria and the UK, e.g. the school system, and have nothing to do with the voting age.

Since potential dynamic effects of changing the voting age would be a major argument in favor of lowering the voting age the question needs a more thorough treatment in a more controlled setting. The real question that needs to be answered in order to be able to say something more definite about the effects of lowering the voting age is conceptually the following: Consider a large sample of identical twins, where one twin in each pair is allowed to vote at 16 and the other one at 18 . Will the twins that

\footnotetext{
${ }^{2}$ Zeglovits and Zandonella (2013) looked at the political interest of 16- and 17-year-olds in Austria before and after the voting age was lowered to 16 in 2007. They found that the political interest of 16- and 17-year-olds surveyed in 2008 was higher than the political interest of 16- and 17-year-olds surveyed in 2004. This is consistent with a reaction to the change in the voting age but Zeglovits and Zandonella (2013) acknowledge that their data makes it impossible to prove a causal relationship.
} 
were allowed to vote at 16, on average, exhibit higher levels of political knowledge and/or political interest at age 16 than the twins that were allowed to vote at 18 ?

Given that very few countries allow 16-year-olds to vote it is hard to obtain data to answer this exact question but in this paper, using nationwide Swedish register data, I answer a very similar question. In Sweden, individuals are allowed to vote if they turn 18 at the latest on the day of the election. This law has been practiced in all elections since 1976 (The Swedish Election Authority [2015]). Utilizing the fact that the Swedish register data gives me access to the exact date of birth of all individuals born in Sweden from 1969 and onwards I can employ a regression discontinuity (RD) strategy to estimate the causal effect of having the first voting opportunity at 18, compared to having the first opportunity, on average, three years later, on a range of measures aimed at capturing political knowledge, political interest and civic interest around age 18. The empirical strategy relies on the assumption that births take place as good as randomly close to the birthdates that serve as the cutoffs for voting eligibility in the elections 18 years later. In other words, individuals that were born just before the cutoff for voting eligibility should be comparable to the individuals born just after (i.e. they should have parents with similar characteristics etc.). Thus, I am able to causally identify the effects of a substantial change of the voting age, albeit on a somewhat higher general age level (i.e. 21 to 18 instead of 18 to 16), on measures of political knowledge and interest. It should be noted that with a voting age of 18 , the average age at first voting opportunity is around 20. If the voting age was lowered to 16 the average age at first voting opportunity would go down to 18 . Thus, this paper investigates voting age effects at a highly relevant margin.

The main measure of political knowledge around age 18 in this paper is the high school grade in Social Studies (Samhällskunskap). According to the objectives of this subject at least $25 \%$ of the grade should be based on the students' political knowledge. This essentially means that political knowledge is measured with a lot of noise. While troublesome for the precision it should not lead to downward bias in the estimates. At the same time this imprecise outcome measure is compensated by the fact that I can employ nationwide registers with large number of observations (relative to surveybased studies like Chan and Clayton [2006] and Wagner et al. [2012]). 
While the subject objectives suggest that the high school grade in Social Studies is a relevant measure of political knowledge it is not perfect. To capture different traces of a potential increase in political knowledge and/or civic interest driven by the voting right that potentially do not show up in the high school grade in Social Studies I also employ two alternative measures. These measures are the performance on the General Knowledge section of the Swedish Scholastic Assessment Test (SweSAT) and the orientation of tertiary studies. The performance on the General Knowledge section of the SweSAT captures knowledge in many different fields but knowledge in Social Science related questions is particularly important (Stage [1985] estimates that about 15 $\%$ of the questions pertain to political knowledge). Since the test is based on multiple choice questions it should be cleansed from "classroom skills" which can contaminate school grades. Early participation in tertiary courses within the core subjects of Social Science is taken as an indicator of high levels of political interest. I also study an outcome variable that takes on the value 1 if the individual has a tertiary education $(\geq 3$ years) within Social Science.

I find that individuals that have the possibility to vote in an election just after their eighteenth birthday do not have higher levels of political knowledge and/or interest around age 18 than comparable individuals whose first voting opportunity takes place, on average, three years later. Individuals with voting right do not have higher high school grades in Social Studies and they do not have better results on the General Knowledge section of the SweSAT. If anything they have worse results but this cannot be definitely established. I also do not find any significant differences between treated and controls with respect to the tertiary education outcomes. Overall, the results suggest that adolescents are unaffected by having the possibility of voting. This finding weakens the case for a lowering of the voting age from 18 to 16, but does not rule out that 16year-olds, at least in some contexts, have sufficient levels of political knowledge for meaningful voting.

The remainder of the paper is structured as follows. In Section 2 I first discuss studies related to potential effects of changing the voting age. I then elaborate on the concept of political knowledge and explain the measures that are used in the paper. Section 3 deals with the data and the institutional setting and in Section 4 I explain the identification strategy. In Section 5 I present the main findings and Section 6 concludes. 


\section{Related literature, political knowledge and measurements}

In this section I first provide a discussion of potential effects of having the right to vote at an early age. This is followed by a short review of the literature on political knowledge. Finally, I discuss the measures of political knowledge, political interest and civic interest that are used in this paper.

\subsection{Voting at an early age}

Several recent studies have used discontinuities caused by voting-age laws to study the effect of early-age voting eligibility on the turnout in later elections (see, e.g. Meredith [2009], Coppock and Green [Forthcoming] and Bhatti et al. [2016]). These studies have found that individuals that can vote shortly after turning 18 have higher future turnout rates than individuals that turn 18 just too late and whose voting debut therefore takes place some years later. While this strongly suggests that voting is habit-forming there is still very little direct evidence on the effect of early-age voting eligibility on early-age political knowledge and interest.

There are, however, related studies reporting positive effects of general political socialization (e.g. community service, election oriented teaching in school and mock voting) during adolescence on civic engagement in early adulthood. First, Hart et al. (2007) find a positive correlation between community service participation in high school and voting and volunteering in early adulthood using longitudinal data on a random sample of U.S high school students. Second, Syvertsen et al. (2009) performed a randomized trial on a small sample of high school students in the U.S. Some of the high school students were randomly assigned to an election-oriented curriculum whereas the other students received the normal education. Syvertsen et al. (2009) then show that the treated students later on expressed higher levels of civic interest and selfreported civic disposition than those in the control condition. Thirdly, Meirick and Wackham (2004) provide evidence indicating that the actual act of casting mock votes in school can deepen the civic commitment of the students. Overall, Hart and Atkins (2011), who advocate a voting age of 16 in the U.S., interpret the collected evidence above as suggesting that, in terms of increased civic engagement, "there likely would be considerable benefits to allowing 16- and 17-year-olds to vote” (Hart and Atkins [2011], p. 217). 
Since these studies use different measures of civic engagement as the outcome and since they do not look at early age voting right per se they cannot be taken as evidence in favor of the existence of dynamic changes in youth political knowledge and interest following a change in the voting age. However, they clearly indicate that teenagers react to different opportunities of political socialization.

\subsection{Political knowledge: Definition, importance and measurement}

Delli Carpini and Keeter (1996) define political knowledge as "the range of factual information about politics that is stored in long-term memory” (Delli Carpini and Keeter [1996], p. 10). As Mondak (2001) points out, the concept of political knowledge lies at the heart of the research on political behavior. Political knowledge is key within political science because it has been found to correlate with, e.g., turnout and political beliefs (see Larcinese [2007] for turnout and Delli Carpini and Keeter [1996] for political beliefs. It is also highly relevant for the voting age debate.

Critics of a lower voting age (e.g. Chan and Clayton, 2006) argue that 16- and 17year-olds lack political knowledge and that it would be detrimental for the quality of democracy to give them the right to vote. If individuals, because of low levels of political knowledge, are unable to identify which political alternative that has the closest correspondence to their own beliefs it might result in the represented political opinions being substantially different from the actual opinions of the citizens. To exemplify with an extreme case, supporters of lower income taxes might, because of ignorance, vote for a party that wants to raise the taxes. Thus, giving the right to vote to individuals that are unable to differentiate between political alternatives is meaningless (see Lau et al. [2008]) or even harmful for democratic legitimacy (see Scharpf [1999]). 16-year-olds might have low levels of political knowledge, relative to their older fellow citizens, when the voting age is 18 but this would not necessarily be the case if the voting age was 16. In fact, as Delli Carpini and Keeter (1996) point out, motivation or the desire to learn is an important requisite for the acquirement of political knowledge and it might respond to changes in the voting age.

Political knowledge is typically measured by asking the subjects a number of questions on factual political knowledge. The questions are normally formulated as propositions and the respondent is asked to determine if they are true or false. Questions can, e.g., be about the name of the prime minister or about the number of parties 
currently represented in the parliament (see Chan and Clayton [2006] for more examples). While questions of this type do not capture all relevant aspects of political knowledge the results from exercises of this type are generally considered good predictors of other political abilities. ${ }^{3}$ Wagner et al. (2012) measure political knowledge by looking at the subjects' ability of placing different parties correctly on the left-toright ideological scale and thus they deviate from the typical factual questions.

\subsection{Measures of political knowledge and political interest used in this paper}

\subsubsection{The Swedish education system}

Since many of the measures used in this paper are related to the Swedish school system it is probably helpful to go through the timing of relevant events. In Sweden, the typical student graduates from junior high school in June of the year when the student turns $16{ }^{4}$ The typical student then starts high school in August of the same year. In high school the students choose between different tracks that normally take three years to complete. Thus, the typical student graduates from high school in the summer of the year when the student turns $19 .{ }^{5}$ In the fall of the same year the students (typically) get the first opportunity of registering for tertiary studies and in the spring of the following year they get the second opportunity and so on.

The elections that I consider in this paper take place in the fall of the year when the relevant students turn 18, i.e. when they have completed about two thirds of their high school education. I assume that the voting right starts to matter about one year before the election, when the election campaign starts to unfold. Thus, conditional on this assumption, students can be affected by the voting right from the second year in high school and onwards. The outcome variables in this paper are typically measured at the end of high school or somewhat later (i.e. around age 19).

\subsubsection{Main measure: high school grade in Social Studies}

The main measure of political knowledge around age 18 in this paper is the high school grade in Social Studies (Samhällskunskap). This subject has 8 objectives (see Table A 1

\footnotetext{
${ }^{3}$ Butt (2004) shows that high levels of factual political knowledge are associated with a better ability of identifying the policy positions of political parties. Thus, individuals with high levels of factual political knowledge should be better at finding parties with opinions that match their own beliefs.

${ }^{4}$ Junior high school is compulsory in Sweden.

${ }^{5}$ It is not compulsory to take part in high school education but over time it has become more and more common and today it is considered necessary for a successful entrance on the labor market (about $98 \%$ of the individuals in a cohort start a high school education). In the main sample of this paper about $70 \%$ have graduated from high school.
} 
in Appendix A). Two of these objectives are directly linked to political knowledge. According to these two objectives the students should (1) understand how the political system works (at different levels) and (2) know how they can influence the decisions within this system (these objectives correspond to points 3 and 4 in Table A 1). In addition, several of the other objectives contain components that are at least related to political knowledge (see objectives 1, 2 and 8 in Table A 1). Thus, at least $25 \%$ of the grade in Social Studies should be based on the students' competence in political knowledge. Political knowledge is therefore measured with noise which should reduce precision but not bias the estimates. On the other hand, the high school grade in Social Studies is readily available which means that I have access to a large number of observations. While studies using survey based measures of political knowledge typically have quite few observations (see Chan and Clayton [2006] and Wagner et al. [2012]) I can use nationwide registers to collect data on high school grades for all individuals that graduated from high school. Consequently, this paper uses a measure that should be affected by the students' level of political knowledge, that is set around age 18 and that is non-missing for a large share of each cohort in modern time.

\subsubsection{Potential problem with the high school grade in Social Studies}

A problem with high school grade in Social Studies is that the grade was potentially set too early for the later cohorts (students that graduated in the years 1997-2010). Those students that graduated from high school at the latest in 1996 got a final grade in the subject Social Studies at the time of graduation. In principle they could affect their grade up to that point but in practice it was probably determined somewhat earlier. Thus, since the lion part of the grade was determined after the point when the voting right (by assumption) started to matter it should be possible to detect a potential voting right effect. Students graduating during the years 1997-2010 on the other hand were graded in courses rather than in subjects and when a course was finished (which could be at the end of the first year) the grade could no longer be influenced. Subsequently a lot of the grades were set long before the actual graduation. During this time there were three courses in Social Studies; Social Studies A, Social Studies B and Social Studies C. All students (no matter what track) took Social Studies A since it was mandatory while (typically) only students in the Social Science track took Social Studies B and Social Studies C. For this period the grade in Social Studies A functions as the main measure 
of the knowledge in Social Studies, while Social Studies B and Social Studies C are used for robustness checks (the B and C courses were taken during the second and third year of high school). A potential problem with using the grade in Social Studies A as a measure of political knowledge is that some students took the course quite early and got the grade after their first year in high school. It is unlikely that having the right to vote influenced those early grades. The variation in the timing of Social Studies A across tracks and across schools was, however, large which makes it a relevant measure for some students but not for others. ${ }^{6}$ In the empirical exercises in Section 5 this late period (1997-2010) is included in the main results but I also look at the early period separately to tackle the problem of the timing of the measurement. In addition I also examine the late period separately with a focus on the courses Social Studies B and C since these were taken at the end of high school and thus have a better timing. Since the high school grade in Social Studies is not a perfect measure of political knowledge I also investigate alternative measures of political knowledge and/or interest in society which I elaborate on in the next section.

\subsubsection{Alternative measures}

The first alternative measure of political knowledge and/or interest in society is the performance on the General Knowledge section of the Swedish Scholastic Assessment Test (SweSAT). The SweSAT is a kind of university admission test in Sweden given twice a year (each spring and fall). It is, however, not compulsory. The university admission is mainly based on high school GPA but for some admissions the students can compete with their SweSAT score. Students (and the rest of the populations as well) can take the SweSAT at any time but it is uncommon to take it before high school. In this paper I consider tests that were taken in the year when a student turned 18, 19 or 20 (i.e. when the student could be affected by having the right to vote). If a student took the test multiple times during this period I keep the first test result. The General Knowledge section was in the test in the years 1977-1995 and consisted of 30 multiple choice questions aimed at capturing the general knowledge about society. The questions could, e.g., be about politics, culture and sports (Stage [1985] estimates that about $15 \%$ of the questions can be categorized as political knowledge). The main advantage with this

\footnotetext{
${ }^{6}$ The data does not allow me to see which students that took the course early and which students that took it late.
} 
measure compared to the high school grade in Social Studies is that it measures factual knowledge which conceptually is how political knowledge is defined.

The second alternative measure is really a measure of political interest. I assume that politically interested individuals to a greater extent than others participate in tertiary studies within the core subjects of Social Science at a young age (before the year when they turn 22). These core subjects are: Economics, Political Science, Economic History, Peace- and development studies and Social and Economic Geography. I also assume that politically interested individuals to a greater extent than others have university degrees in subjects within Social Science. Due to data constraints a broader definition of Social Science is used for the degrees.

The overall objective with all the discussed measures is to capture different traces of a potential increase in political knowledge and/or civic interest driven by the voting right around or somewhat after the time of the election.

\section{$3 \quad$ Institutional setting and data}

In this section I present details of the Swedish voting system and provide a list of Swedish elections during the period 1988-2006. I further describe some important details of the sample restrictions and end with a discussion of the data.

\subsection{Institutional setting: elections in Sweden}

In Sweden, citizens are eligible to vote if they are 18 years of age at the latest on the day of the election. After several changes in the voting eligibility law during the 1960s the above law was passed in 1975 and has since been in force (The Swedish Election Authority [2015]). This means that all elections from 1976 and onwards generate local experiments for the individuals close to the eligibility threshold.

The study uses rich Swedish register data with access to complete birth date information for all individuals born in Sweden from 1969 and onwards. This property of the data enables me to perform regression discontinuity analyses with exact day of birth as the running variable ${ }^{7}$ for all elections from 1988 and onwards. Consequently, data limitations rules out using elections prior to 1988. At the other end of the timeline I am restricted by the fact that I only can observe register data up to and including the spring

\footnotetext{
${ }^{7}$ In the RD terminology, the variable that determines if an individual is treated or not is often called the running variable. In this case the birth date determines if an individual has the right to vote or not. The term running variable will be used throughout the study.
} 
semester of 2010. Thus, I can only use elections prior to 2010 (which means that 2006 is the last election to the Swedish Parliament). In Table 1 I provide a list of all Swedish elections during the period 1988-2006.

The list contains 6 elections to the Swedish parliament, 3 elections to the European parliament and 2 referendums. As we see in Table 1, the elections to the European parliament generally have substantially lower turnout rates than the other elections. Effectively, this means that they are low-status elections and that they are unlikely to stimulate youth civic engagement and knowledge acquirement. Thus, elections to the European parliament will not be included in this study. Additionally, in order for the age at the first voting opportunity to be substantially different between the individuals on the two respective sides of the cutoffs I only include elections where the subsequent election takes places at least one year later (this restriction is not relevant if the subsequent election is to the European Parliament).

In summary, as Table 1 indicates, the following seven elections are used in this paper: Swedish parliament 1988, Swedish parliament 1991, referendum on EU 1994, Swedish parliament 1998, Swedish parliament 2002, referendum on the EURO 2003 and Swedish parliament 2006.

Table 1. Elections in Sweden 1988-2006

\begin{tabular}{lcccc}
\hline Type of election & Date of election & $\begin{array}{c}\text { Birth cutoff date for } \\
\text { eligibility }\end{array}$ & Turnout rate & Used in the study \\
\hline SP election & $09 / 18 / 1988$ & $09 / 18 / 1970$ & $86.0 \%$ & Yes \\
SP election & $09 / 15 / 1991$ & $09 / 15 / 1973$ & $86.7 \%$ & Yes \\
SP election & $09 / 18 / 1994$ & $09 / 18 / 1976$ & $86.8 \%$ & No \\
Referendum & $11 / 13 / 1994$ & $11 / 13 / 1976$ & $83.3 \%$ & Yes \\
EP election & $09 / 17 / 1995$ & $09 / 17 / 1977$ & $41.6 \%$ & No \\
SP election & $09 / 20 / 1998$ & $09 / 20 / 1980$ & $81.4 \%$ & Yes \\
EP election & $06 / 13 / 1999$ & $06 / 13 / 1981$ & $38.8 \%$ & No \\
SP election & $09 / 15 / 2002$ & $09 / 15 / 1984$ & $80.1 \%$ & Yes \\
Referendum & $09 / 14 / 2003$ & $09 / 14 / 1985$ & $82.6 \%$ & Yes \\
EP election & $06 / 13 / 2004$ & $06 / 13 / 1986$ & $37.9 \%$ & No \\
SP election & $09 / 17 / 2006$ & $09 / 17 / 1988$ & $81.9 \%$ & Yes \\
\hline
\end{tabular}

Notes: $\mathrm{SP}=$ Swedish Parliament. EP=European Parliament. $\mathrm{a}=\mathrm{EU}, \mathrm{b}=\mathrm{EURO}$. Information on all elections comes from Statistics Sweden (2015). 


\subsection{Data: sample restrictions}

To avoid potential problems with comparing individuals belonging to different school cohorts I only study individuals that turn 18 during one of the seven election years. Adopting this restriction implies that the "controls" with respect to the referendum in 1994 are those born in the interval November 14, 1976 to December 31, 1976. This interval consists of 48 days. Note that no other election takes place later in the year; consequently the interval of 48 days can be used throughout the study which creates consistency across elections. Thus, each one of the seven elections will have a maximum treatment period of 48 days (the 47 days directly before the eligibility cutoff date and the eligibility cutoff date itself) as well as a maximum control period that consists of the 48 days that directly follows after the eligibility cutoff date. Table 2 clarifies the birth dates that have been used to construct the sample of treated and the sample of controls.

Table 2. Samples of treated and controls

\begin{tabular}{lll}
\hline Election & Treated & Controls \\
\hline SP 1988 & $08 / 02 / 1970$ to 09/18/1970 & $09 / 19 / 1970$ to $11 / 05 / 1970$ \\
SP 1991 & $07 / 30 / 1973$ to 09/15/1973 & $09 / 16 / 1973$ to $11 / 02 / 1973$ \\
Referendum 1994 & $09 / 27 / 1976$ to $11 / 13 / 1976$ & $11 / 14 / 1976$ to $12 / 31 / 1976$ \\
SP 1998 & $08 / 04 / 1980$ to 09/20/1980 & $09 / 21 / 1980$ to $11 / 07 / 1980$ \\
SP 2002 & $07 / 30 / 1984$ to 09/15/1984 & $09 / 16 / 1984$ to $11 / 02 / 1984$ \\
Referendum 2003 & $07 / 29 / 1985$ to 09/14/1985 & $09 / 15 / 1985$ to $11 / 01 / 1985$ \\
SP 2006 & $08 / 01 / 1988$ to 09/17/1988 & $09 / 18 / 1988$ to $11 / 04 / 1988$ \\
\hline
\end{tabular}

Notes: The period consists of 48 days before and after the cutoff dates.

The birth date of every individual has then been normalized by the subtraction of the respective cutoff dates, generating seven election specific normalized birth dates. ${ }^{8}$ Only observations with a normalized birth date that lies in the interval $[-47,48]$ stay in the data. A problem with using the exact day of birth in this context is that previous evidence (see Dickert-Conlin and Elder[(2010]) indicates that there are systematic differences between week days with respect to births, i.e. children born on weekends tend to be somewhat different from children born on weekdays (with respect to parental characteristics). To tackle this issue I aggregate up the data to full weeks. Individuals

\footnotetext{
${ }^{8}$ A normalized birth date of 0 thus indicates that the individual turned 18 on the day of the election. A non-positive number thus indicates eligibility in the election and vice versa.
} 
with a normalized birth date in the interval [-6,0] will then belong to week 0 and individuals with a normalized birth date in the interval [1,7] will belong to week 1 . Given that I kept individuals with a normalized birth date in the range $[-47,48]$ the week numbers will go from -6 to $7 .{ }^{9}$ Within these boundaries the bandwidth will be varied in the empirical exercises in Section 5.

\subsection{Data: descriptive statistics}

Table 3 describes some descriptive statistics for the two samples specified in Table 2 Overall, the number of individuals born on the dates specified in Table 2 is 172,283. The treated individuals (i.e. those who have the chance to vote just after turning 18) amount to 87,977 and the controls consist of 84,306 individuals. The fact that the sample contains more treated individuals is expected considering that the number of births typically is lower at the end of a year. As we can see in Table 3 the treated individuals get their first opportunity to vote in a first-order election about three years before the controls (age 18 compared to age 21) which is arguably a substantial difference. From previous evidence it is known that individuals born earlier in the year normally have stronger educational outcomes. This is confirmed in the data by looking at the Junior High School GPA (standardized by graduation year) which is a predetermined covariate. ${ }^{10}$ Treated individuals have a higher GPA on average and fewer of them lack $^{11}$ information on this variable, indicating higher educational ambition already before the treatment (i.e. the opportunity to vote in a first-order election). The same pattern can be seen for the Junior High School grade in Social Studies which constitutes a predetermined measure of political knowledge. There are generally small differences between the two groups with respect to parental characteristics. ${ }^{12}$

\footnotetext{
${ }^{9}$ Note that weeks -6 and 7 only contain 6 days. In the empirical analysis I also present results using the exact normalized birth date as the running variable to the test robustness of the results. Weekday indicators are then included in the empirical model.

${ }^{10} \mathrm{I}$ assume that the voting right starts to matter approximately one year before the election, when the election campaign starts to unfold. Thus, conditional on that assumption all variables that are determined before that point in time can be considered predetermined (i.e. they should be unaffected by the treatment).

${ }^{11}$ I do not have access to Junior High School data for the individuals that turned 18 in in 1988.

${ }^{12}$ For those that turned 18 in 1998, 2002, 2003 or 2006 the parental characteristics are measured at age 15. For those that turned 18 in 1988 the parental characteristics are measured at age 20. For those that turned 18 in 1991 the parental characteristics are measured at age 17. For those that turned 18 in 1994 the parental characteristics are measured at age 18. This is due to data constraints. Even if the parental characteristics are measured after age 15 for some individuals they are arguably good proxies for the parental characteristics at age 15 since it is unlikely that the child's voting right affects the parents.
} 
Looking at the outcome variables at the bottom of Table 3 we see that treated individuals have a somewhat better high school grade in Social Studies ${ }^{13}$ and that they have a slightly higher score on the General Knowledge section in the SweSAT. This is of course consistent with a positive treatment effect but it is clear that a simple comparison of outcomes between the two groups is confounded by unbalanced covariates (i.e. the Junior High School grades). This problem can be solved by comparing individuals that are infinitely close to the threshold that separates the two groups, and in the next section I describe this research design in detail. When it comes to the tertiary education outcomes at the very bottom of Table 3 the treated and controls exhibit identical summary statistics.

Table 3. Descriptive statistics for the most widely used sample

\begin{tabular}{|c|c|c|c|c|}
\hline Characteristics & & & & \\
\hline & $\begin{array}{c}\text { Nonmissing } \\
\text { data (All) }\end{array}$ & All & $\begin{array}{l}\text { Voting } \\
\text { right=1 }\end{array}$ & $\begin{array}{l}\text { Voting } \\
\text { right }=0\end{array}$ \\
\hline \multicolumn{5}{|l|}{ Demographics } \\
\hline Male & 1 & 0.514 & 0.514 & 0.513 \\
\hline Age at first major voting opp. & 1 & 19.532 & 18.065 & 21.064 \\
\hline \multicolumn{5}{|l|}{ Predetermined variables } \\
\hline JHS Overall GPA & 0.812 & -0.038 & -0.026 & -0.050 \\
\hline JHS grade in Social Studies & 0.812 & -0.027 & -0.018 & -0.037 \\
\hline Mother tertiary education $\geq 3$ years & 0.982 & 0.135 & 0.135 & 0.135 \\
\hline Father tertiary education $\geq 3$ years & 0.945 & 0.142 & 0.143 & 0.142 \\
\hline Mother in work & 0.983 & 0.856 & 0.858 & 0.854 \\
\hline Father in work & 0.951 & 0.879 & 0.879 & 0.880 \\
\hline \multicolumn{5}{|l|}{ Outcome variables } \\
\hline HS grade in Social Studies & 0.677 & -0.015 & -0.009 & -0.020 \\
\hline SweSAT score (General Knowledge)* & 0.084 & -0.248 & -0.238 & -0.258 \\
\hline Early registration Social Science** & 0.847 & 0.017 & 0.017 & 0.017 \\
\hline 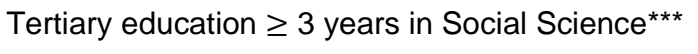 & 0.539 & 0.021 & 0.021 & 0.021 \\
\hline Observations & 172,283 & 172,283 & 87,977 & 84,306 \\
\hline
\end{tabular}

Notes: JHS=Junior High School. HS=High School. All grade measures are standardized within graduation year. The SweSAT score is standardized within a given test. * Only individuals that turned 18 in 1988, 1991 or 1994 can have data on this variable. ** Individuals that turned 18 in 1988 cannot have data on this variable due to data constraints. *** Only individuals that turned 18 in 1988, 1991, 1994 or 1998 can have data on this variable. This is due to the fact that it is measured in 2009 and cannot be considered completed education for the later cohorts.

\footnotetext{
${ }^{13}$ To have data on this variable the individuals must have a grade in Social Studies and they must graduate from high school during the year when they turn 18, 19 or 20.
} 


\section{Empirical specification}

I employ a regression discontinuity design on the data, using birth cutoff dates for voting eligibility to create exogenous variation in the voting age. Under the assumption that births take place randomly around the birth cutoff dates for voting eligibility this method allows me to estimate the causal effect of early age voting right on the relevant outcomes. The normalized week number is used as the running variable and it is denoted by $Z_{i e}$ where $e$ indicates the specific election. ${ }^{14}$ Equation (1) specifies the baseline empirical model used in the paper:

$Y_{i}=\beta_{0}+\beta_{1} I\left[Z_{i e} \leq 0\right]+\beta_{2} Z_{i e}+\beta_{3} I\left[Z_{i e} \leq 0\right] * Z_{i e}+\delta_{e}+u_{i}$

The outcome, denoted $Y_{i}$, is a measure aimed at capturing political knowledge and/or political interest. $\delta_{e}$ captures election specific fixed effects and $u_{i}$ is an error term. I include separate linear terms on the two sides of the threshold (i.e. $\beta_{2} Z_{i e}$ and $\beta_{3} I\left[Z_{i e} \leq\right.$ $0] * Z_{i e}$ ) and $\beta_{1}$ captures the difference between the two linear terms as they approach the threshold from below and above respectively. Under the assumption that the underlying confounders are continuous in the running variable (i.e. $Z_{i e}$ ) around the threshold, this difference (i.e. $\beta_{1}$ ) corresponds to the causal effect of early voting eligibility on the relevant outcome (see, e.g., Lee and Lemieux (2010) for a detailed discussion of the identifying assumptions underlying the typical RD design). Essentially, this procedure amounts to running separate local linear regressions on both sides of the threshold and comparing the values of those regressions at the cutoff. The specific data window (bandwidth) within which this is performed should be varied to test the robustness of the results and this is done in Section 5.2. ${ }^{15}$ Following the advice of Lee and Card (2008) on the appropriate choice of standard errors when using a discrete running variable I cluster the standard errors on the week-times-election level.

\footnotetext{
${ }^{14}$ In this setting we have e=1988, 1991, 1994, 1998, 2002, 2003 and 2006. For some outcomes a subset of these elections are used.

${ }^{15}$ The possible windows are: $[0,1],[-1,2] \ldots[-6,7]$. However, it is considered good practice to have at least four unique values of the forcing variable below the cutoff and four unique values above the cutoff (Schochet et al. (2010)).
} 


\section{$5 \quad$ Results}

In this section I first examine the research design to make sure that the underlying identifying assumption is valid. I then present the main results.

\subsection{Tests of the identifying assumption}

The underlying identifying assumption that is required in order to make causal interpretations of the treatment effect in this context is that all potential confounders are continuous in the running variable (i.e. the normalized birth week $Z_{i e}$ ) across the threshold. This assumption amounts to requiring random assignment to treatment in the immediate proximity of the threshold. The typical way of testing this assumption is to investigate if the running variable evolves smoothly over the cutoff and if predetermined variables (i.e. variables that were determined before the elections) are continuous around the cutoff conditional on the empirical model, i.e. Equation 1 (See Lee and Lemieux [2010]). Mass points in the running variable close to the threshold raise concerns about the manipulability of the running variable, and jumps in the predetermined variables at the cutoff are yet another indication of manipulation.

Before going in to the empirical exercises, let us first consider the running variable and the cutoffs that are used in this paper. Since the cutoffs refer to voting eligibility birthdate thresholds for elections that take place 18 years later it seems highly unlikely that parents are able to manipulate births to take place before rather than after a cutoff. ${ }^{16}$ Even if the birthdate cutoffs were perfectly predictable we would arguably not expect strategic timing of births at these cutoffs. Dickert-Conlin and Elder (2010), e.g., do not even find strategic timing of births at thresholds that determine age at school start which is an outcome that arguably carries more significance than early age voting eligibility. Thus, unlike most other RD-settings where being on the right side of a threshold is associated with substantial personal benefits (e.g. access to certain schools and eligibility for social benefits) the context in this paper offers small incentives for manipulation of the running variable.

Since the main measure in this paper is the high school grade in Social Studies the pre-tests are performed on the sample with valid information on this variable $(67.7 \%$ of the total sample, see Table 3). Figure 1 shows the distribution of the running variable

\footnotetext{
${ }^{16}$ Anecdotally, parents do not behave in that way. And if they did it would be a difficult practice since election legislation tends to change over time. Examples of such changes can be the time between the elections and the voting age. Thus, it is virtually impossible to predict the timing of elections far in the future.
} 
around the voting eligibility birth date cutoffs. There is no indication of that abnormally many individuals were born in the weeks just before the cutoffs (i.e. in weeks -1 and 0 ). Instead, the number of births during the weeks around the cutoffs evolves smoothly and this visual impression is also confirmed by the McCrary density test which delivers an insignificant result. ${ }^{17}$

Figure 1. Distribution of the running variable

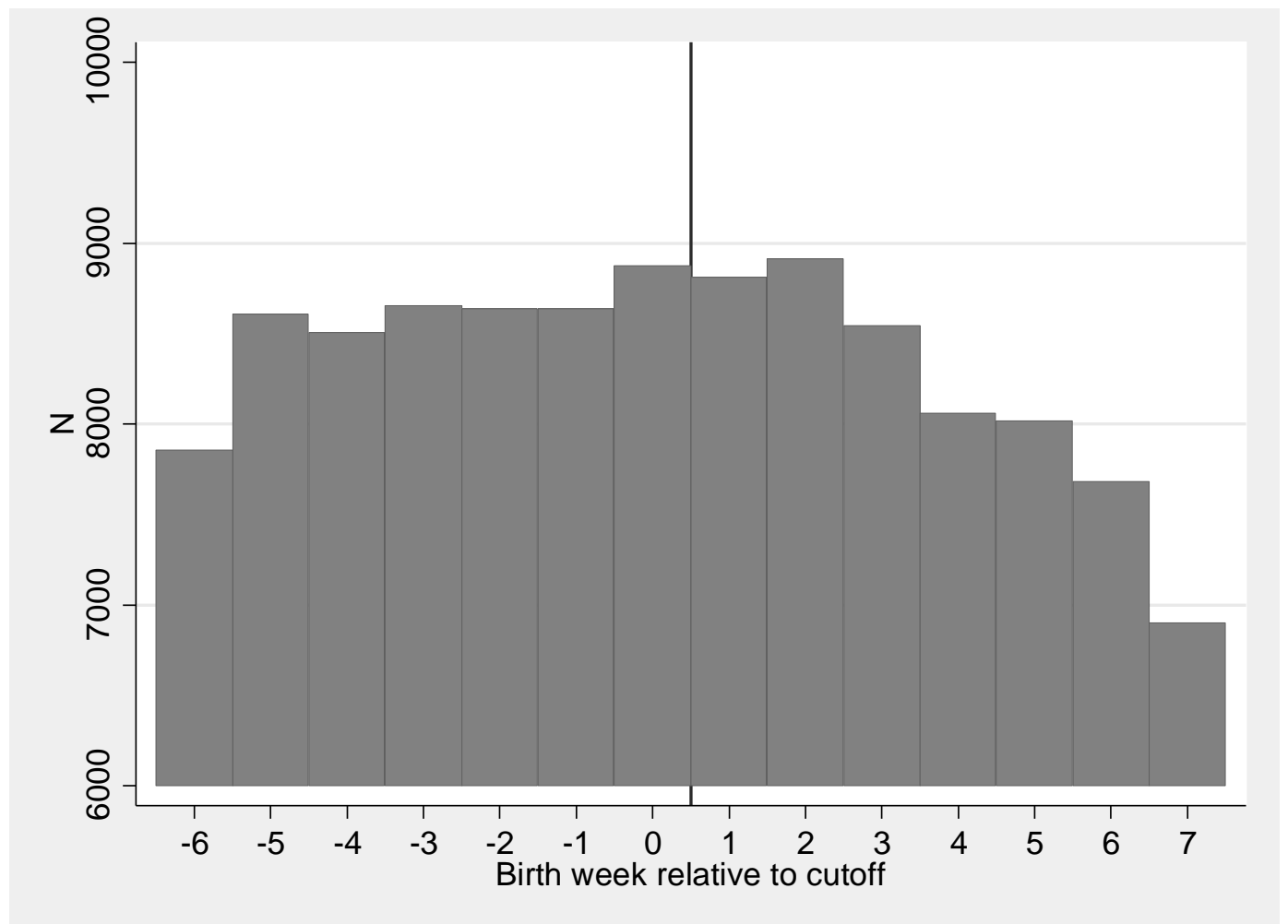

Notes: The figure is based on individuals with valid information on the high school grade in Social Studies. The sample amounts to 116,713 observations.

As a next step I examine if any of the predetermined variables (see Table 3) behave strangely at the cutoff. Figure 2 shows the relation between the running variable and the Junior High School grade in Social Studies. ${ }^{18}$ I choose to highlight this relation since the Junior High School grade in Social Studies is a predetermined measure of political knowledge which is the main outcome in this paper and thus a key predetermined variable. As expected there is a negative relation between the grade and the running variable since individuals born late in the year typically have worse educational

\footnotetext{
${ }^{17}$ The p-value is 0.473 . The null hypothesis is that the discontinuity in the density of the running variable at the cutoff is zero. See McCrary (2008) for a detailed description of the test.

${ }^{18}$ The fact that the standardized grade lies around 0.2 is due to that only individuals that have graduated from high school are studied here. These individuals generally have good pre high school educational outcomes.
} 
outcomes. Individuals that can vote shortly after turning 18 (i.e. with non-positive values on the running variable) generally have a higher grade but importantly the grade evolves smoothly over the cutoff suggesting that individuals close the cutoff are similar with respect to the Junior High School grade in Social Studies. Similar graphs of all predetermined variables can be found in Figure B 1 in Appendix B and they generally paint a similar picture.

Figure 2. Relation between JHS grade in Social Studies and the running variable

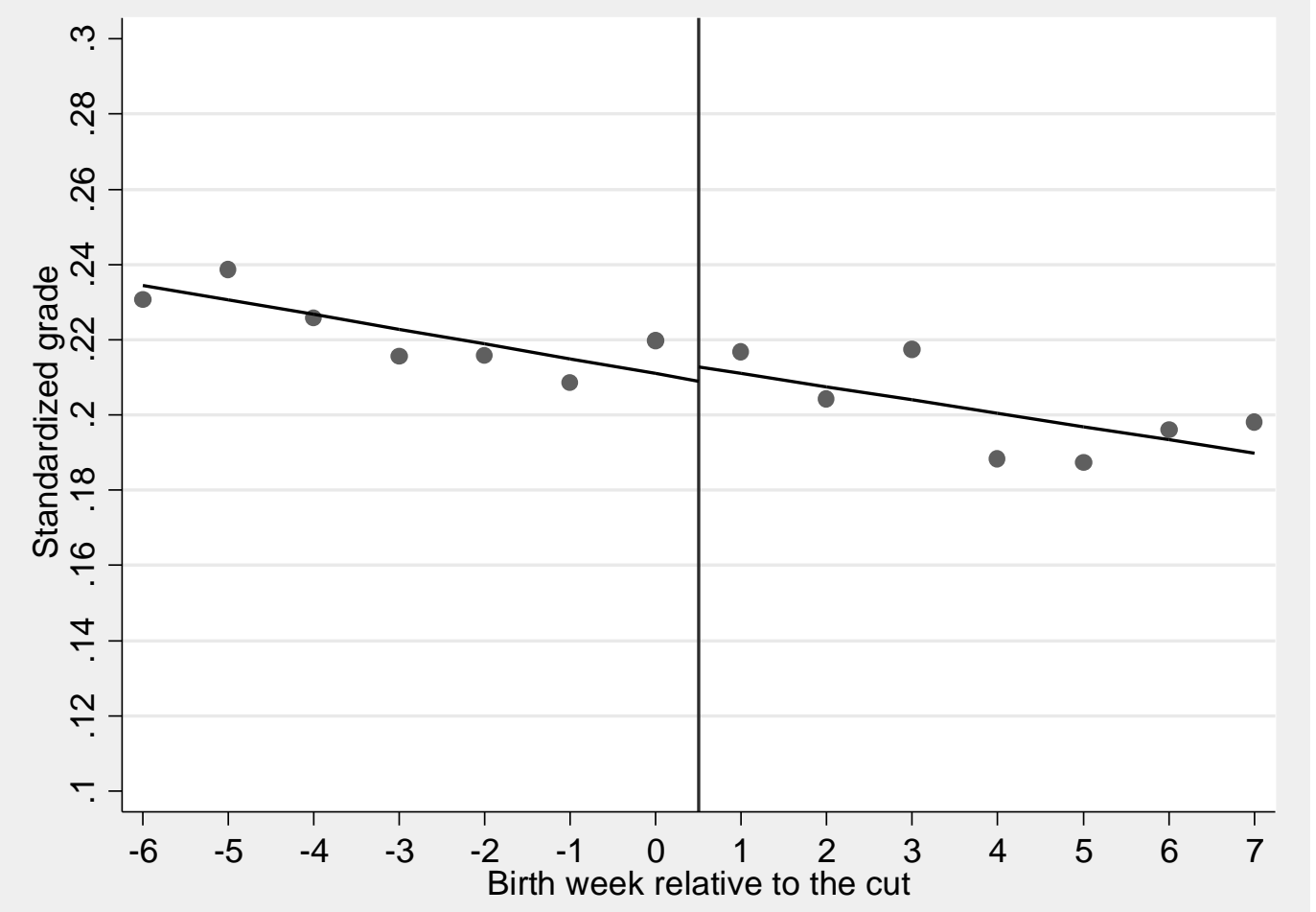

Notes: The figure is based on individuals with valid information on the high school and junior high school grade in Social Studies. The sample amounts to 102,191 observations.

In Table 4 the predetermined variables are given a more formal treatment within a regression framework. All estimates come from the model specified in Equation (1) and the full bandwidth is used (i.e. the running variable goes from -6 to 7 ). The estimates are generally small and insignificant and thus consistent with the identifying assumption of random assignment to treatment at the thresholds. Importantly, as can be seen in the bottom of Table 4, the estimates exhibit joint insignificance which further strengthens the validity of the research design. Table B 1 in Appendix B shows estimates from regressions using alternative specifications of the empirical model (i.e. smaller bandwidth and quadratic control for the running variable). The results from these 
alternative specifications do not substantially deviate from the estimates shown in Table 4 which provides additional evidence of the robustness of the empirical strategy.

Table 4. Regression discontinuity estimates for the predetermined variables

\begin{tabular}{|c|c|c|c|c|c|c|}
\hline Column: & (1) & (2) & (3) & (4) & (5) & (6) \\
\hline Outcome: & $\begin{array}{c}\text { JHS } \\
\text { Overall GPA }\end{array}$ & $\begin{array}{l}\text { JHS grade } \\
\text { Social Stud. }\end{array}$ & $\begin{array}{c}\text { Mother highly } \\
\text { educated }\end{array}$ & $\begin{array}{c}\text { Father highly } \\
\text { educated }\end{array}$ & $\begin{array}{c}\text { Mother } \\
\text { employed }\end{array}$ & $\begin{array}{c}\text { Father } \\
\text { employed }\end{array}$ \\
\hline Voting right & $\begin{array}{l}-0.0064 \\
(0.0095)\end{array}$ & $\begin{array}{l}-0.0037 \\
(0.0117)\end{array}$ & $\begin{array}{l}-0.0001 \\
(0.0052)\end{array}$ & $\begin{array}{c}0.0043 \\
(0.0055)\end{array}$ & $\begin{array}{l}-0.0031 \\
(0.0041)\end{array}$ & $\begin{array}{l}-0.0050 \\
(0.0037)\end{array}$ \\
\hline Mean of dep. & 0.241 & 0.212 & 0.166 & 0.175 & 0.882 & 0.901 \\
\hline Observations & $\begin{array}{c}102,191 \\
p \text {-value for the }\end{array}$ & $\begin{array}{c}102,191 \\
\text { st of joint sig }\end{array}$ & $\begin{array}{c}115,321 \\
\text { icance of the }\end{array}$ & $\begin{array}{c}111,904 \\
\text { stimates:0.32 }\end{array}$ & 115,405 & 112,437 \\
\hline
\end{tabular}

Notes: The results are based on individuals with valid information on the high school grade in Social Studies and non-missing data on the relevant variable. JHS=Junior High School.

To make sure that there are no confounding elements at the cutoffs because of potential seasonal variations I have also constructed fake cutoffs. These cutoffs are constructed to take place either the year before or the year after the real cutoffs. ${ }^{19}$ I then estimate the effect of being on the treatment side of these cutoffs on the high school grade in Social Studies (which constitutes the main outcome) conditional on the empirical model. As expected the results, which are presented in Table 5, do not include any significant estimates. The estimates are somewhat sensitive to the choice of empirical specification but generally the results hover around 0 . This is reassuring for the research design since it means that any potential true treatment effects should be due to the voting right and not to any confounding seasonal factors.

\footnotetext{
${ }^{19}$ I have constructed fake birth date cutoffs in 1969 (real 1970), 1972 (real 1973), 1975 (real 1976), 1979 (real 1980), 1983 (real 1984), 1986 (real 1985) and 1987 (real 1988). The fake cutoffs are set on the same weekday in the same week as the real cutoffs (thus not necessarily on the same date).
} 
Table 5. Regression discontinuity estimates for the high school grade in Social Studies (Fake election cutoffs)

\begin{tabular}{|c|c|c|c|c|c|c|c|}
\hline Column: & $(1)$ & (2) & (3) & (4) & (5) & (6) & (7) \\
\hline Bandwidth: & {$[-6,7]$} & {$[-5,6]$} & {$[-4,5]$} & {$[-3,4]$} & {$[-6,7]$} & {$[-6,7]$} & \\
\hline Voting right & $\begin{array}{c}-0.0021 \\
(0.0133)\end{array}$ & $\begin{array}{c}0.0025 \\
(0.0142)\end{array}$ & $\begin{array}{c}0.0104 \\
(0.0143)\end{array}$ & $\begin{array}{c}0.0148 \\
(0.0155)\end{array}$ & $\begin{array}{c}0.0260 \\
(0.0252)\end{array}$ & $\begin{array}{c}0.0054 \\
(0.0117)\end{array}$ & $\begin{array}{c}0.0000 \\
(0.0112)\end{array}$ \\
\hline Mean of dep. & -0.0096 & -0.0083 & -0.0090 & -0.0083 & -0.0096 & -0.0096 & -0.0096 \\
\hline Observations & 108,518 & 99,252 & 83,173 & 67,180 & 108,518 & 108,518 & 108,518 \\
\hline Linear control & Yes & Yes & Yes & Yes & Yes & Yes & Yes \\
\hline Election FE & Yes & Yes & Yes & Yes & Yes & Yes & Yes \\
\hline Quadratic control & No & No & No & No & Yes & No & No \\
\hline Predetermined var. & No & No & No & No & No & Yes & No \\
\hline Day of birth as RV & No & No & No & No & No & No & Yes \\
\hline Weekday FE & No & No & No & No & No & No & Yes \\
\hline
\end{tabular}

Notes: Standard errors are clustered on week * election level. */**/*** significant at the $10 / 5 / 1$ percent level. $\mathrm{RV}=$ running variable.

\subsection{Main results}

This section contains results from regression discontinuity analyses of three different groups of outcomes all aimed at capturing different aspects of political knowledge and/or civic interest. I discuss the high school grade in Social Studies, the score on the General knowledge section of the SweSAT and the orientation of tertiary studies in turn.

A substantial part of the main sample lacks data on the high school grade in Social Studies and the score on the General knowledge section of the SweSAT and to make sure that there is no selection into having a grade or a score at the cutoff I have investigated the effect of the voting right on indicators for having a grade or a score. These results are presented in Table B 2 in Appendix B. Some of the estimates for the high school grade in Social Studies are marginally significantly positive but this result is not robust to reducing the bandwidth or including predetermined variables in the model. Overall the analysis suggests that we cannot reject the null hypothesis of no selection into having a grade or a score. Any difference in the actual outcomes between the individuals on the respective sides of the cutoff should therefore be attributed to the voting right and not to different probabilities of having a non-missing outcome. 


\subsubsection{High school grade in Social Studies}

I start the presentation of the actual results with investigating potential early age voting right effects on the high school grade in Social Studies which constitutes my main measure of political knowledge around age $18 .^{20}$ Figure 3 shows the relationship between the high school grade in Social Studies and the running variable. Consistent with the picture in Figure 2 we see a negative relationship between the grade and the running variable. Individuals that had the right to vote just after turning 18 have a higher grade than the controls on average but treated individuals right at the threshold actually have lower grades than the corresponding controls. The negative estimate is however small (about $1.3 \%$ of a standard deviation) and insignificant. Importantly, there is no evidence at all of a positive jump in the outcome at the threshold which goes against the hypothesis of voting right induced increases in political knowledge (see Wagner et al. 2012).

Figure 3. Relation between HS grade in Social Studies and the running variable

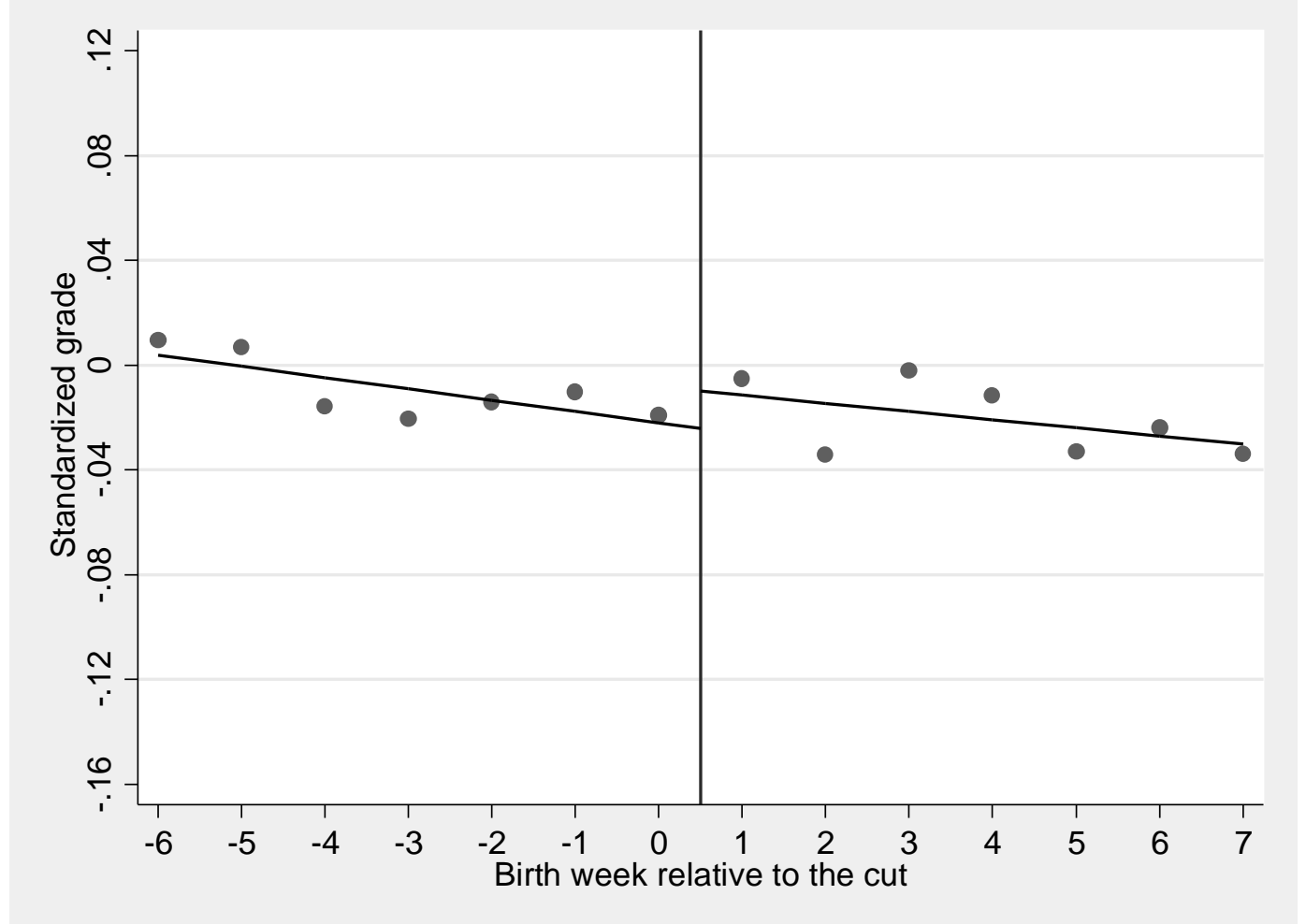

Notes: The figure is based on individuals with valid information on the high school grade in Social Studies. The sample amounts to 116,713 observations.

\footnotetext{
${ }^{20}$ For those who graduated at the latest in 1996, the measure is based on the grade in the subject Social Studies. For those who graduated in 1997-2010 the measure is based on the grade in the course Social Studies A.
} 
Table 6 (panel A) provides formal estimates of the effect of having the opportunity to vote at a relatively young age on the high school grade in Social Studies conditional on seven different empirical specifications where specification (1) corresponds to the difference at the cutoff in Figure 3. In columns (2-4) the bandwidth is gradually reduced which leads to a lower estimate in absolute terms. It actually becomes positive in column (4) where I only use four data points on each side of the cutoff. In column (5) I introduce quadratic controls for the running variable which also gets the estimate closer to zero compared to specification (1). In column (6) I include the predetermined variables which increase the precision but only marginally affect the estimate in relation to specification (1). In column (7) I use exact day of birth as the running variable instead of the week variable and control for potential differences between the days of the week by including weekday fixed effects. The estimate is virtually the same as in specification (1). Since the estimates from these different specifications generally are on the negative side and never substantially positive they suggest that there is no positive voting right effect on political knowledge around age 18.

The table also includes alternative measures of the grade in Social Studies (see Section 2.3.3 for a discussion of the timing problem of the grade). In panel B I focus on the early period (i.e. individuals born in 1970, 1973 or 1976) when the individuals were given a final grade in the subject Social Studies. In panels C and D I focus on the late period (i.e. individuals born in 1980, 1984, 1985 or 1988) when the students could take advanced courses in Social Studies. These courses (i.e. Social Studies B and C) were taken at the end of high school and are thus measured at a good time in relation to the voting opportunity.

Panel B gives a similar picture to panel A but the estimates are generally more negative and in fact never on the positive side. The effect is of a magnitude of about 2 $\%$ of a standard deviation and it is quite robust to changes in the empirical model. Again there is absolutely no support for a positive voting right effect. Panels C and D report similar results with the estimates firmly on the negative side. The estimates in column (5), the model with predetermined variables included, are actually significantly negative. But it should be noted that relatively few students take these courses which leaves us with a substantial uncertainty. 
The overall message to take away from Table 6 is that we generally find negative but insignificant effects of voting right on political knowledge. This suggests that positive effects of practically relevant magnitudes can be ruled out.

Table 6. Regression discontinuity estimates for the high school grade in Social Studies

\begin{tabular}{|c|c|c|c|c|c|c|c|}
\hline Column: & (1) & $(2)$ & (3) & (4) & (5) & (6) & (7) \\
\hline Bandwidth: & {$[-6,7]$} & {$[-5,6]$} & {$[-4,5]$} & {$[-3,4]$} & {$[-6,7]$} & {$[-6,7]$} & {$[-6,7]$} \\
\hline \multicolumn{8}{|c|}{ Panel A: The high school grade in Social Studies, whole period } \\
\hline \multirow[t]{2}{*}{ Voting right } & -0.0131 & -0.0094 & -0.0058 & 0.0036 & 0.0010 & -0.0095 & -0.0141 \\
\hline & $(0.0113)$ & $(0.0121)$ & $(0.0127)$ & $(0.0141)$ & $(0.0164)$ & $(0.0083)$ & $(0.0114)$ \\
\hline Mean of dep. & -0.0147 & -0.0153 & -0.0167 & -0.0149 & -0.0147 & -0.0147 & -0.0147 \\
\hline Observations & 116,713 & 101,955 & 85,668 & 69,140 & 116,713 & 116,713 & 116,713 \\
\hline \multicolumn{8}{|c|}{ Panel B: The high school grade in Social Studies, early period } \\
\hline \multirow[t]{2}{*}{ Voting right } & -0.0155 & -0.0110 & -0.0281 & -0.0224 & -0.0276 & -0.0124 & -0.0178 \\
\hline & $(0.0181)$ & $(0.0199)$ & $(0.0221)$ & $(0.0228)$ & $(0.0272)$ & $(0.0156)$ & $(0.0178)$ \\
\hline Mean of dep. & -0.0310 & -0.0330 & -0.0339 & -0.0303 & -0.0310 & -0.0310 & -0.0310 \\
\hline Observations & 44,968 & 39,222 & 32,986 & 26,511 & 44,968 & 44,968 & 44,968 \\
\hline \multicolumn{8}{|c|}{ Panel C: The high school grade in Social Studies B } \\
\hline \multirow[t]{2}{*}{ Voting right } & $-0.0437^{*}$ & -0.0456 & -0.0198 & -0.0485 & -0.0279 & $-0.0636^{\star \star \star}$ & -0.0416 \\
\hline & $(0.0260)$ & $(0.0287)$ & $(0.0316)$ & $(0.0303)$ & $(0.0389)$ & $(0.0201)$ & $(0.0338)$ \\
\hline Mean of dep. & 0.0105 & 0.0118 & 0.0150 & 0.0101 & 0.0105 & 0.0105 & 0.0105 \\
\hline Observations & 12,638 & 11,060 & 9,308 & 7,598 & 12,638 & 12,638 & 12,638 \\
\hline \multicolumn{8}{|c|}{ Panel D: The high school grade in Social Studies C } \\
\hline \multirow[t]{2}{*}{ Voting right } & -0.0752 & -0.0738 & -0.0466 & -0.0715 & -0.0558 & $-0.0786^{\star \star}$ & -0.0746 \\
\hline & $(0.0486)$ & $(0.0517)$ & $(0.0565)$ & $(0.0600)$ & $(0.0793)$ & $(0.0363)$ & $(0.0469)$ \\
\hline Mean of dep. & 0.0160 & 0.0149 & 0.0183 & 0.00978 & 0.0160 & 0.0160 & 0.0160 \\
\hline Observations & 6,440 & 5,636 & 4,740 & 3,877 & 6,440 & 6,440 & 6,440 \\
\hline Linear control & Yes & Yes & Yes & Yes & Yes & Yes & Yes \\
\hline Election FE & Yes & Yes & Yes & Yes & Yes & Yes & Yes \\
\hline Quadratic control & No & No & No & No & Yes & No & No \\
\hline Predetermined var. & No & No & No & No & No & Yes & No \\
\hline Day of birth as RV & No & No & No & No & No & No & Yes \\
\hline Weekday FE & No & No & No & No & No & No & Yes \\
\hline
\end{tabular}

Notes: Standard errors are clustered on week * election level. */**/*** significant at the $10 / 5 / 1$ percent level. 


\subsubsection{Score on the General Knowledge section of the SweSAT}

The score on the General Knowledge section of the SweSAT offers a possibility of capturing the studied individuals' levels of factual knowledge about society. In that respect the SweSAT General Knowledge score resembles the definition of political knowledge given by Delli Carpini and Keeter (1996) (see Section 2.2) but it has a wider scope with questions that, besides politics, encompass e.g. news, culture and sports. Stage (1985) estimates that about $15 \%$ of the questions in the test pertain to political knowledge. The General Knowledge section of the SweSAT was removed after 1995 and subsequently only the three early elections (i.e. the elections in 1988, 1991 and 1994) can be used to study this outcome. ${ }^{21}$

In Table 7 I provide estimates of the effect of having the possibility of voting shortly after turning 18, relative to 21, on the SweSAT score in General Knowledge. In column (1) I present the baseline estimate (the same kind of estimate as in Figure 3 but this time for the SweSAT score in General Knowledge). It is negative and amounts to about 3.5 $\%$ of a standard deviation. When the bandwidth is reduced (columns [2-4]) the estimates come closer to zero in relation to the baseline estimate. And when quadratic controls for the running variable are introduced in column (5) we obtain a positive estimate of about $3 \%$ of a standard deviation. Including predetermined variables (column [6]) makes the estimate more negative in relation to specification (1) while using day of birth as the running variable (column [7]) just barely affects the estimate.

The estimates are generally on the negative side but the results are clearly sensitive to the choice of empirical model. The conclusion can therefore not be that there is a robust negative effect, but rather that it is unlikely that there is a positive effect on General Knowledge measured around age 18 from having the opportunity to vote just after turning 18.

\footnotetext{
${ }^{21}$ I include tests that were taken during the year when the individual turned 18, 19 or 20 . Thus, for individuals that turned 18 in 1988 I include tests taken in 1988-1990. If the test was taken multiple times I keep the result from the first test. Due to data constraints I can only include tests taken in 1994 and 1995 for the individuals that turned 18 in 1994.
} 
Table 7. Regression discontinuity estimates for the SweSAT score (General Knowledge section)

\begin{tabular}{|c|c|c|c|c|c|c|c|}
\hline Column: & $\begin{array}{c}(1) \\
{[-67]}\end{array}$ & $\begin{array}{c}(2) \\
{[-56]}\end{array}$ & $\begin{array}{c}(3) \\
{[-45]}\end{array}$ & (4) & $\begin{array}{c}(5) \\
{[-67]}\end{array}$ & $\begin{array}{c}(6) \\
{[-67]}\end{array}$ & $\begin{array}{c}(7) \\
{[-67]}\end{array}$ \\
\hline Bandwidth: & {$[-6,7]$} & {$[-5,6]$} & {$[-4,5]$} & {$[-3,4]$} & {$[-6,7]$} & {$[-6,7]$} & \\
\hline Voting right & $\begin{array}{l}-0.0343 \\
(0.0260)\end{array}$ & $\begin{array}{l}-0.0257 \\
(0.0290)\end{array}$ & $\begin{array}{c}0.0062 \\
(0.0282)\end{array}$ & $\begin{array}{c}0.0077 \\
(0.0343)\end{array}$ & $\begin{array}{c}0.0310 \\
(0.0378)\end{array}$ & $\begin{array}{c}-0.0524^{\star \star \star} \\
(0.0191)\end{array}$ & $\begin{array}{l}-0.0297 \\
(0.0320)\end{array}$ \\
\hline Mean of dep. & -0.248 & -0.245 & -0.239 & -0.247 & -0.248 & -0.248 & -0.248 \\
\hline Observations & 14,538 & 12,685 & 10,657 & 8,480 & 14,538 & 14,538 & 14,538 \\
\hline Linear control & Yes & Yes & Yes & Yes & Yes & Yes & Yes \\
\hline Election FE & Yes & Yes & Yes & Yes & Yes & Yes & Yes \\
\hline Quadratic control & No & No & No & No & Yes & No & No \\
\hline Predetermined var. & No & No & No & No & No & Yes & No \\
\hline Day of birth as RV & No & No & No & No & No & No & Yes \\
\hline Weekday FE & No & No & No & No & No & No & Yes \\
\hline
\end{tabular}

\subsubsection{Tertiary studies within Social Science}

If political socialization during adolescence leads to an increased inclination towards civic engagement later in life as Hart and Atkins (2011) argue then we would expect early age voters to choose tertiary educations within Social Science to a greater extent than comparable individuals whose first chance of voting takes places 2-3 years later (when the choice of tertiary education already might have been made). In Table 8 I study two measures of Social Science involvement at the university.

The outcome in panel $\mathrm{A}$ is an indicator for early registration in a tertiary course within the core subjects of Social Science. Early registration is defined as before the year when an individual turns 22 and the core subjects are: Economics, Political Science, Economic History, Peace- and development studies and Social and Economic Geography. The baseline estimate in column (1) is slightly negative and it is virtually unaffected by the variations in the empirical model that it is subjected to in columns (27). In fact, all estimates are on the negative side and they are all insignificant. A $95 \%$ confidence interval does include positive estimates but at a magnitude that hardly can be seen as practically relevant.

The outcome in panel B is an indicator for having completed a tertiary education of at least three years within Social Science. Due to data constraints Social Science is here more broadly defined than in panel $\mathrm{A}$, and in addition to the subjects mentioned above it also includes subjects like Sociology and Psychology. The education level is measured 
in 2009 and since it is supposed to capture completed education I only study individuals that turned 18 in 1988, 1991, 1994 or 1998 . The overall picture is similar to the one in panel A, with the estimates consistently on the negative side. Since the estimate is more or less the same over all seven specifications it seems unlikely that any reasonable model can generate substantial positive estimates. Therefore I interpret the collected evidence from this exercise as suggesting that adolescents are virtually unaffected with respect to political/civic interest by having the possibility of voting shortly after turning 18.

Table 8. Regression discontinuity estimates for tertiary studies within Social Science

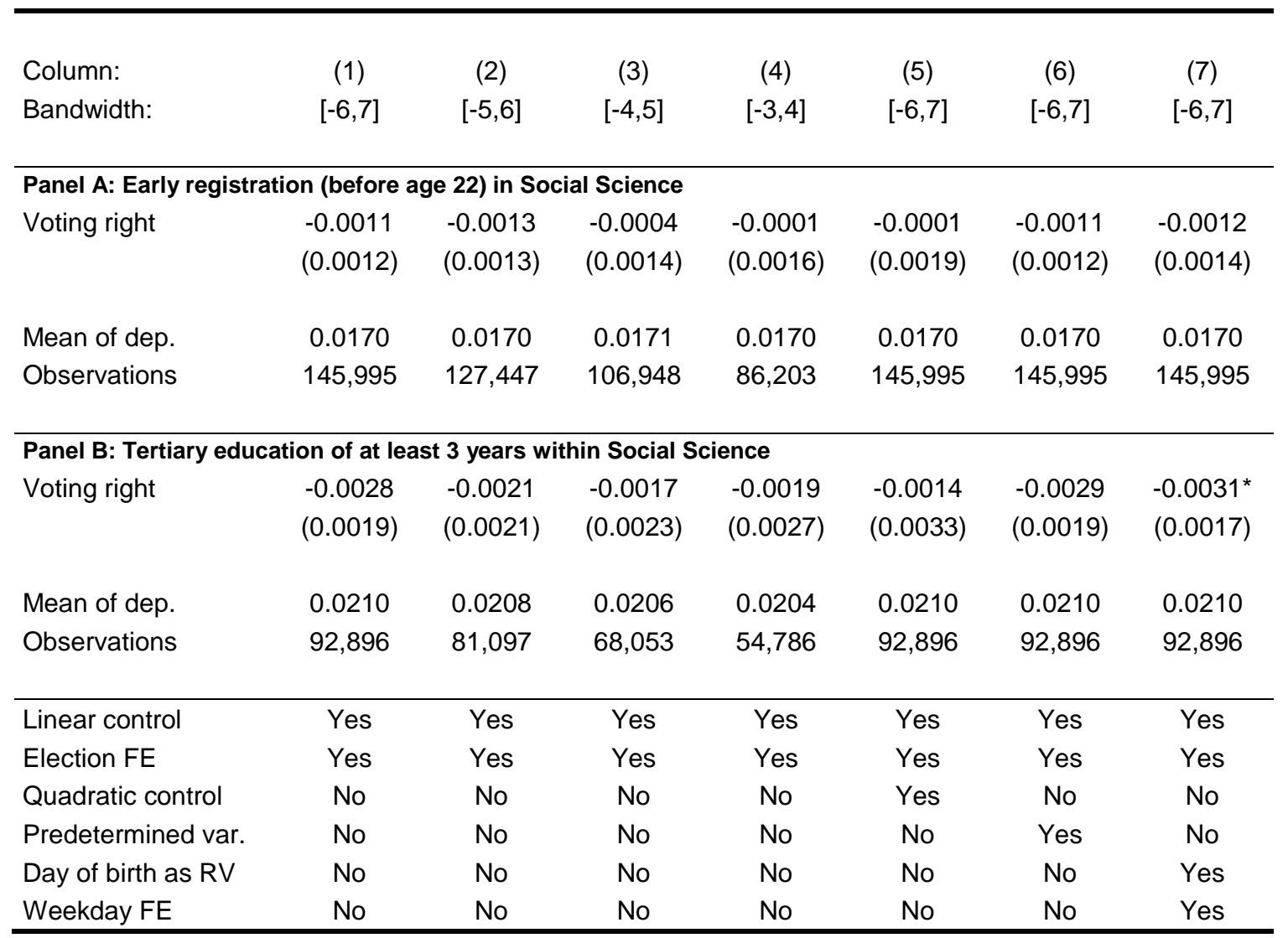

Notes: Standard errors are clustered on week * election level. */**/*** significant at the $10 / 5 / 1$ percent level. $\mathrm{RV}=$ running variable.

\subsection{Heterogeneity analyses}

Some individuals might be more affected by having the right to vote shortly after turning 18 than others. Experiences from Swedish elections clearly show that females have higher turnout rates than males among young voters. Another robust finding is that individuals with highly educated parents have higher turnout rates than individuals with 
parents with low levels of education. ${ }^{22}$ Individuals with highly educated parents are probably also more likely to be informed about their voting right in the election at an early stage. Based on these observations I perform a number of exercises separately for males and females and for individuals whose parents have high respectively low levels of education. ${ }^{23}$ If anything there should be a higher probability of detecting positive voting right effects among women and among individuals with highly educated parents since they are more likely to be affected by having the right to vote.

I present the main results in Table 9 and robustness checks in Table B 3 and Table B 4 in Appendix B. For simplicity and ease of presentation I restrict the analysis to two outcome variables: the high school grade in Social Studies (panel A of Table 9 and Table B 3) and the SweSAT score on General Knowledge (panel B of Table 9 and Table B 4). These two measures are closest connected to the concept of political knowledge.

With respect to the high school grade in Social Studies (panel A of Table 9) the point estimates are negative for all groups and actually more negative for women and individuals with highly educated parents. Changing the empirical specification (e.g. reducing the bandwidth and including quadratic controls for the running variable) does not affect the estimates for women and individuals with highly educated parents (see Table B 3). Thus, it is possible to rule out the existence of positive effects for these groups. For males and individuals without highly educated parents the results are, however, more sensitive to empirical model. Models with small bandwidths and with quadratic controls for the running variable generate positive estimates which makes the conclusion less clear for these groups. But an average over the seven specifications suggests a zero effect.

The results for the SweSAT score on General Knowledge are more in line with the hypothesis considering that females have the least negative estimate (and several estimates for females in Table B 4 are actually significantly positive). On the other hand individuals with highly educated parents exhibit strongly negative estimates, which is hard to reconcile with the hypothesis. It should be noted that these estimates suffer from bad precision because of small sample sizes which suggests that the results should be interpreted with caution. But at the very least I think we can rule out the existence of

\footnotetext{
${ }^{22}$ See Sveriges Kommuner och Landsting (2009). The report is in Swedish and is written by the association of Swedish local and regional governments.

${ }^{23}$ Individuals who have at least one parent with at least three years of tertiary education are defined as having highly educated parents.
} 
positive effects for males and individuals with highly educated parents. The picture is less clear for females and individuals without highly educated parents but it should be noted that specification (6) in Table B 4, which arguably has the strongest identification because of the inclusion of predetermined variables, report negative estimates.

In summary no single group stands out as being particularly influenced by having the right to vote.

Table 9. Heterogeneity analyses (gender and family background)

Column:

Bandwidth:

Group:
(1)

$[-6,7]$

Males
(2)

$[-6,7]$

Females
(3)

$[-6,7]$

HE parents
(4)

$[-6,7]$

Not HE parents

\begin{tabular}{|c|c|c|c|c|}
\hline \multicolumn{5}{|c|}{ Panel A: The high school grade in Social Studies } \\
\hline Voting right & $\begin{array}{l}-0.0090 \\
(0.0158)\end{array}$ & $\begin{array}{l}-0.0168 \\
(0.0141)\end{array}$ & $\begin{array}{l}-0.0168 \\
(0.0188)\end{array}$ & $\begin{array}{l}-0.0114 \\
(0.0113)\end{array}$ \\
\hline Mean of dep. & -0.143 & 0.0987 & 0.366 & -0.143 \\
\hline Observations & 54,735 & 61,978 & 29,365 & 87,348 \\
\hline \multicolumn{5}{|c|}{ Panel B: The SweSAT score on General Knowledge } \\
\hline Voting right & $\begin{array}{l}-0.0711 \\
(0.0477)\end{array}$ & $\begin{array}{l}-0.0052 \\
(0.0294)\end{array}$ & $\begin{array}{l}-0.0571 \\
(0.0372)\end{array}$ & $\begin{array}{l}-0.0162 \\
(0.0329)\end{array}$ \\
\hline Mean of dep. & -0.0159 & -0.432 & -0.0409 & -0.371 \\
\hline Observations & 6,435 & 8,103 & 5,432 & 9,106 \\
\hline Linear control & Yes & Yes & Yes & Yes \\
\hline Election fixed effects & Yes & Yes & Yes & Yes \\
\hline Quadratic control & No & No & No & No \\
\hline Predetermined variables & No & No & No & No \\
\hline Day of birth as running variable & No & No & No & No \\
\hline Weekday fixed effects & No & No & No & No \\
\hline
\end{tabular}

\section{Conclusion}

The typical voting age around the world is 18 . However, during the last ten years the appropriateness of this traditional voting age has been challenged. In 2007, Austria lowered the voting age to 16 , and 16- and 17-year-olds were also allowed to vote in the Scottish independence referendum in 2014. These events were the results of, and have contributed to, a discussion of the advantages and disadvantages of lowering the voting age to 16 . Proponents of a lower voting age have emphasized that 16- and 17-year-olds 
very well might respond by becoming more politically knowledgeable (see Wagner et al. [2012]) and interested (see Zeglovits and Zandonella [2013]) if they are allowed to vote. It has also been suggested that early age voting leads to a deeper civic commitment in adulthood. This claim has been ventilated in both popular (see Brooks [2014] for the comments by Alex Salmond) and scientific contexts (see Hart and Atkins [2011]). If true, these arguments build a strong case for a lowering of the voting age to 16. However, given the current evidence it is hard to validate these claims since they have not been analysed in a controlled causal framework.

In this paper I have therefore used rich nation-wide Swedish register data to contribute with this kind of evidence. Swedish voting laws state that citizens are eligible to vote if they turn 18 at the latest on the day of the election. Utilizing the fact that the Swedish register data gives me access to the exact date of birth of all individuals born in Sweden from 1969 and onwards I can employ a regression discontinuity (RD) strategy to estimate the causal effect of having the first voting opportunity at 18, compared to having the first opportunity, on average, three years later, on measures of political knowledge, political interest and civic interest around age 18. As expected there is no evidence of manipulation of the running variable at the thresholds that I use in the paper and therefore I cannot reject the null of random assignment to early voting opportunity at the voting eligibility birthdate cutoffs. Thus, I am able to causally identify the effects of a substantial reduction of the voting age, albeit on a somewhat higher general age level (i.e. 21 to 18 instead of 18 to 16), on political knowledge, political interest and civic interest in early adulthood.

Political knowledge and interest is mainly measured using the high school grade in Social Studies but the score on the General Knowledge section in the SweSAT is also used as an alternative measure which captures a combination of political and civic interest and knowledge. Civic interest is further measured by examining the orientation of tertiary studies (i.e. are the individuals involved in Social Science studies?).

To the extent that my measures can be said to capture political knowledge, political interest and civic interest around and shortly after age 18 the collected evidence from the $\mathrm{RD}$ analyses show that individuals that had their first voting opportunity in a firstorder election shortly after turning 18 do not exhibit higher levels of the aforementioned outcomes than comparable individuals whose first voting opportunity in a major 
election took place, on average, three years later. This finding strongly indicates that the putative benefits of a lower voting age, in terms of increased political and civic interest, are false or at least severely exaggerated. Thus, this argument should be used with extreme caution in the voting age debate. However, it is of course possible that the teaching in school would change if the voting age was 16 so that political science material would be introduced at an earlier age. In that case 16-year-olds would probably become more politically knowledgeable following a decrease in the voting age but that would be the result of a changed teaching rather than a change in the motivation to learn more about politics among the 16-year-olds.

Finally, even if the conclusion in this study rejects one of the key arguments for a lowering of the voting age it does not imply that it necessarily is wrong to lower the voting age to 16 , rather it suggests that 16-year-olds will not rise to the occasion and become more politically knowledgeable just because they are given the right to vote. There might still be a case for a voting age of 16 , or even lower, on the basis of general human rights considerations as Wagner et al. (2012) suggest, and this discussion would surely benefit from further scientific contributions of empirical as well as theoretical nature. 


\section{References}

Bhatti, Y., Hansen, K. M. and Wass, H. (2016), "First-time boost beats experience: the effect of past eligibility on turnout”, Electoral Studies, 41, 151-158.

Brooks, L. (2014, September 23), “Alex Salmond calls for voting age to be lowered in time for general election”, The Guardian, Accessed July $29^{\text {th }} 2015$. < http://www. theguardian.com/politics/2014/sep/23/alex-salmond-scottish-independencereferendum-exhilarating>.

Butt, S. (2004), "Political Knowledge and Routes to Party Choice in the British General Election of 2001”, British Elections and Parties Review, 14, 3-17.

Central Intelligence Agency. (2015), “The World Factbook”. Accessed July 30 2015. $<$ https://www.cia.gov/library/publications/the-world-factbook/>.

Chan, T. W. and Clayton, M. (2006), "Should the voting age be lowered to sixteen? Normative and empirical considerations”, Political Studies, 54(3), 533-558.

Coppock, A. and Green, D. P. (Forthcoming), "Is Voting Habit Forming? New Evidence from Experiments and Regression Discontinuities”, American Journal of Political Science.

Delli Carpini, M. X. and Keeter, S. (1996), "What Americans Know about Politics and Why it Matters”, Yale University Press, New Haven.

Dickert-Conlin, S. and Elder, T. (2010), “Suburban legend: School cutoff dates and the timing of births”, Economics of Education Review, 29(5), 826-841.

Hart, D., Donnelly, T. M., Youniss, J. and Atkins, R. (2007), "High school community service as a predictor of adult voting and volunteering”, American Educational Research Journal, 44(1), 197-219.

Hart, D. and Atkins, R. (2011), “American sixteen-and seventeen-year-olds are ready to vote", The ANNALS of the American Academy of Political and Social Science, 633(1), 201-222.

Human Rights Advocates. (2009), “The right to Vote: A Basic Human Right in Need of Protection”, Manuscript, Accessed October $13^{\text {th }} 2015$. <http://www.humanrights 
advocates.org/wp-content/uploads/2010/05/The-Right-to-Vote-A-Basic-HumanRight-In-Need-of-Protection.pdf $>$.

Larcinese, V. (2007), "Does political knowledge increase turnout? Evidence from the 1997 British general election”, Public Choice, 131(3-4), 387-411.

Lau, R. R., Andersen, D. J. and Redlawsk, D. P. (2008), “An exploration of correct voting in recent US presidential elections”, American Journal of Political Science, 52(2), 395-411.

Lee, D. S. and Card, D. (2008), "Regression discontinuity inference with specification error”, Journal of Econometrics, 142, 655-674.

Lee, D. S. and Lemieux, T. (2010), "Regression Discontinuity Designs in Economics”, Journal of Economic Literature, 48(2), 281-355.

McCrary, J. (2008), "Manipulation of the running variable in the regression discontinuity design: A density test”, Journal of Econometrics, 142(2), 698-714.

Meirick, P. C. and Wackman, D. B. (2004), "Kids Voting and Political Knowledge: Narrowing Gaps, Informing Votes”, Social Science Quarterly, 85(5), 1161-1177.

Meredith, M. (2009), “Persistence in political participation”, Quarterly Journal of Political Science, 4(3), 187-209.

Mondak, J. J. (2001), “Developing Valid Knowledge Scales”, American Journal of Political Science, 45(1), 224-38.

Scharpf, F. (1999), “Governing in Europe: Effective and Democratic?”, Oxford University Press, Oxford.

Schochet, P., Cook, T., Deke, J., Imbens, G., Lockwood, J. R., Porter, J. and Smith, J. (2010), “Standards for Regression Discontinuity Designs”, Retrieved from What Works Clearinghouse website: http://ies.ed.gov/ncee/wwc/pdf/wwc_rd.pdf.

Stage, Christina. (1985), “Group differences in test results. The significance of test item contents for sex differences in results on vocabulary and general knowledge”, Doctoral dissertation at the Department of Education, University of Umeå.

Statistics Sweden. Accessed August $5^{\text {th }}$ 2015. <http://www.scb.se>. 
Swedish Association of Local Authorities and Regions. 2009. "Valdeltagande bland förstagångsväljare (Turnout among first time voters)”. (in Swedish).

Syvertsen, A. K., Stout, M. D., Flanagan, C. A., Mitra, D. L., Oliver, M. B. and Sundar, S. S. (2009), “Using elections as teachable moments: A randomized evaluation of the student voices civic education program”, American Journal of Education, 116(1), $33-67$.

The Swedish Election Authority. (2015), Accessed August $5^{\text {th }}$ 2015. <http://www. val.se/det_svenska_valsystemet/historik/index.html>.

The Swedish National Agency for Education. (2015). Accessed August $5^{\text {th }} 2015$. $<$ http://www.skolverket.se/laroplaner-amnen-ochkurser/gymnasieutbildning/gymnasieskola/kursplaner-fore2011/subjectKursinfo.htm?subjectCode=SH\&courseCode=SH1201\&lang=sv\#anchor _SH1201>

The Telegraph. (2012, November 1), “Argentina lowers voting age to 16”, Accessed October $14^{\text {th }} 2015$. <www.telegraph.co.uk/news/worldnews/southamerica/argentina/ 9647629/Argentina-lowers-voting-age-to-16.html>.

The United Nations. (1948), “Universal Declaration of Human Rights”, Accessed October $13^{\text {th }}$ 2015. <http://www.un.org/Overview/rights.html>.

UK Government. Accessed July 30 ${ }^{\text {th }}$ 2015. < https://www.gov.uk/government/topicalevents/scottish-independence-referendum/about $>$.

Wagner, M., Johann, D. and Kritzinger, S. (2012), "Voting at 16: Turnout and the quality of vote choice”, Electoral studies, 31(2), 372-383.

Zeglovits, E. and Zandonella, M. (2013), "Political interest of adolescents before and after lowering the voting age: the case of Austria”, Journal of Youth Studies, 16(8), 1084-1104. 


\section{Appendix A: additional information on measures}

Table A 1. Course objectives for Social Studies A (Samhällskunskap A)

The students should:

1. Have knowledge about the evolution and function of democracy and be able to apply democratic working methods (ha kunskap om demokratins framväxt och funktion samt kunna tillämpa ett demokratiskt arbetssätt)

2. Be able to understand how political, economic, geographical and social conditions have formed and continue to form our own society as well as the international community (kunna förstå hur politiska, ekonomiska, geografiska och sociala förhållanden har format och ständigt påverkar såväl vårt eget samhälle som det internationella samhället)

3. Have knowledge about the function of the political system on the local, regional and national level as well as in the EU (ha kunskaper om det politiska systemets funktion på lokal, regional, nationell och EUnivå)

4. Be able to understand how one can influence political decisions on the local, regional and national level as well as in the EU and internationally (kunna förstå hur man kan påverka politiska beslut på lokal, regional och nationell nivå, inom EU samt internationellt)

5. Be able to formulate, understand and reflect upon social issues using historical as well as future perspectives (kunna formulera, förstå och reflektera över samhällsfrågor ur såväl historiska som framtida perspektiv)

6. Be able to apply ethical and environmental perspectives on different social issues (kunna lägga etiska och miljömässiga perspektiv på olika samhällsfrågor)

7. Be able to use different sources of knowledge and methods when working with social issues (kunna använda olika kunskapskällor och metoder vid arbetet med samhällsfrågor)

8. Understand how opinions and attitudes come about and be aware of how values and stances are formed (känna till hur åsikter och attityder uppstår samt vara medveten om hur värderingar och ställningstaganden formas)

Notes: This information comes from The Swedish National Agency for Education (2015). The original Swedish formulations are in parentheses. 


\section{Appendix B: additional results}

Figure B 1. The relationship between the predetermined variables and the running variable
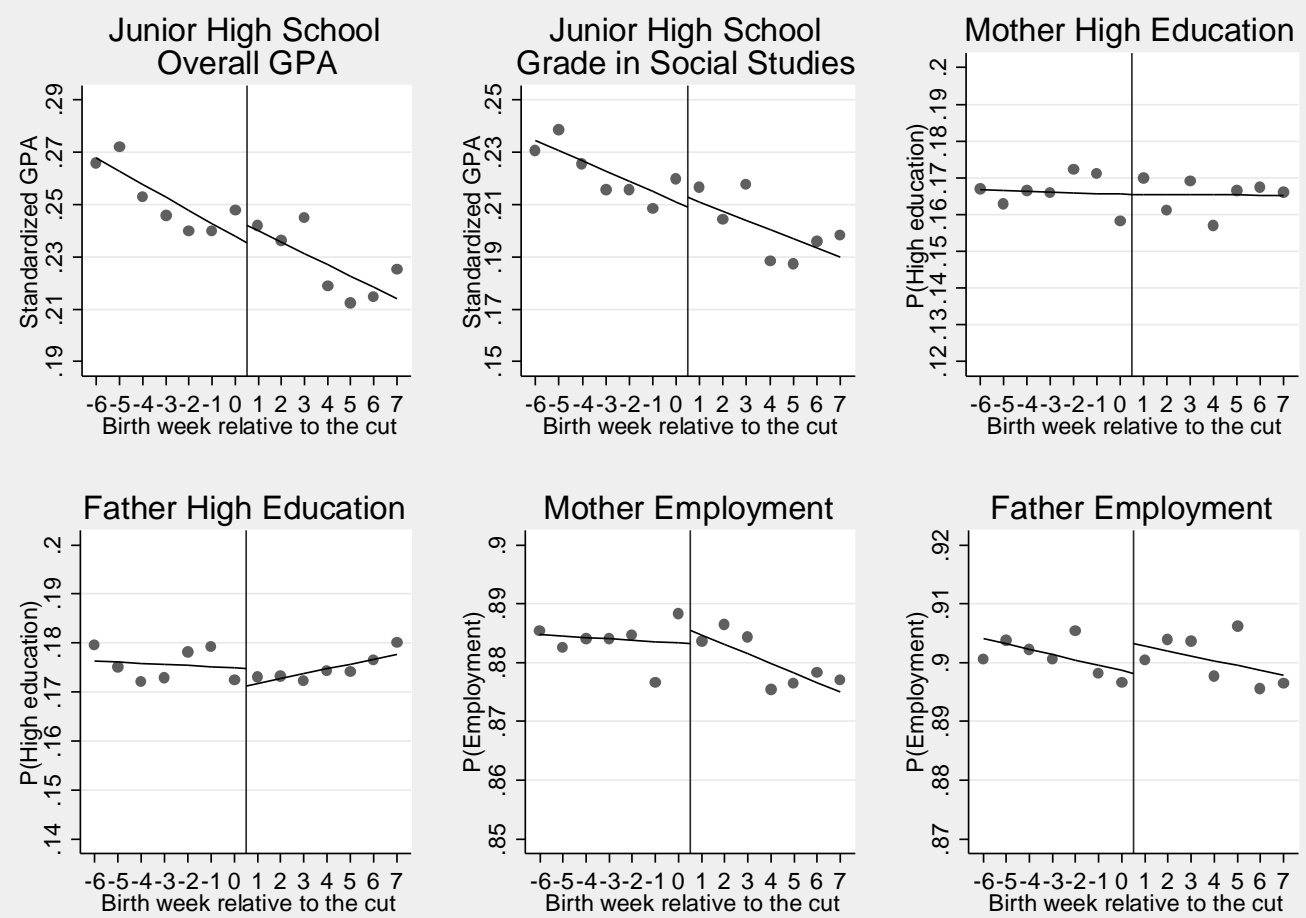

Notes: The figures are based on individuals with valid information on the high school grade in Social Studies and non-missing data on the relevant variable. 
Table B 1. Regression discontinuity estimates for the predetermined variables

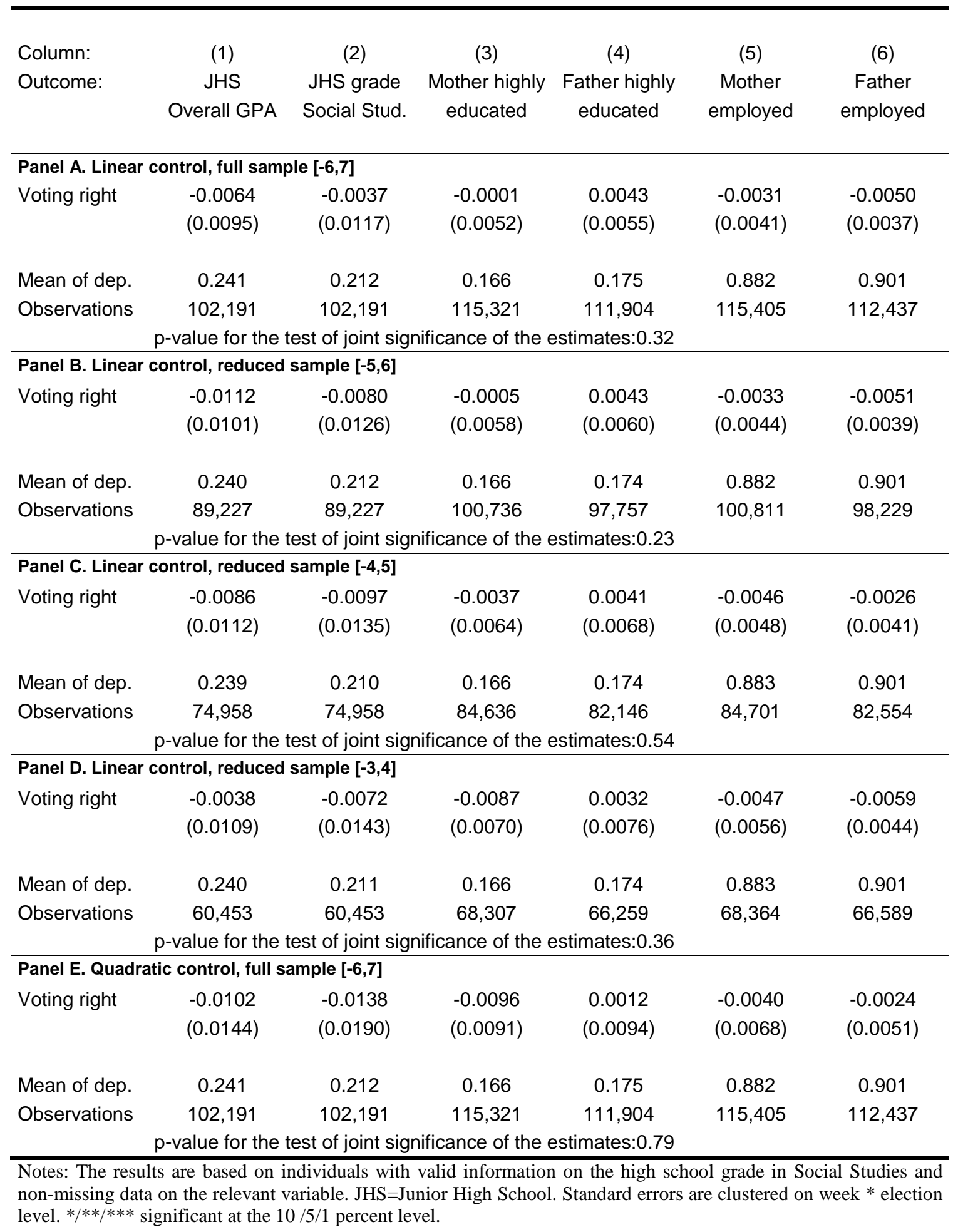


Table B 2. Is there a selection into having a grade or a test result?

\begin{tabular}{|c|c|c|c|c|c|c|c|}
\hline Column: & (1) & (2) & (3) & (4) & (5) & (6) & $(7)$ \\
\hline Bandwidth: & {$[-6,7]$} & {$[-5,6]$} & {$[-4,5]$} & {$[-3,4]$} & {$[-6,7]$} & {$[-6,7]$} & {$[-6,7]$} \\
\hline \multicolumn{8}{|c|}{ Panel A: Indicator for having a high school grade in Social Studies } \\
\hline Voting right & $\begin{array}{l}0.0065^{\star} \\
(0.0039)\end{array}$ & $\begin{array}{l}0.0082^{*} \\
(0.0042)\end{array}$ & $\begin{array}{l}0.0096 * * \\
(0.0045)\end{array}$ & $\begin{array}{c}0.0056 \\
(0.0054)\end{array}$ & $\begin{array}{c}0.0103 \\
(0.0064)\end{array}$ & $\begin{array}{c}0.0057 \\
(0.0035)\end{array}$ & $\begin{array}{c}0.0073 \\
(0.0045)\end{array}$ \\
\hline Mean of dep. & 0.677 & 0.677 & 0.678 & 0.678 & 0.677 & 0.677 & 0.677 \\
\hline Observations & 172,283 & 150,566 & 126,383 & 101,923 & 172,283 & 172,283 & 172,283 \\
\hline \multicolumn{8}{|c|}{ Panel B: Indicator for having a SweSAT result } \\
\hline Voting right & $\begin{array}{l}-0.0016 \\
(0.0063)\end{array}$ & $\begin{array}{l}-0.0008 \\
(0.0066)\end{array}$ & $\begin{array}{l}-0.0050 \\
(0.0077)\end{array}$ & $\begin{array}{l}-0.0015 \\
(0.0081)\end{array}$ & $\begin{array}{c}0.0017 \\
(0.0092)\end{array}$ & $\begin{array}{l}-0.0019 \\
(0.0045)\end{array}$ & $\begin{array}{c}-0.0014 \\
(0.0051)\end{array}$ \\
\hline Mean of dep. & 0.195 & 0.195 & 0.195 & 0.193 & 0.195 & 0.195 & 0.195 \\
\hline Observations & 74,527 & 65,103 & 54,640 & 43,908 & 74,527 & 74,527 & 74,527 \\
\hline Linear control & Yes & Yes & Yes & Yes & Yes & Yes & Yes \\
\hline Election FE & Yes & Yes & Yes & Yes & Yes & Yes & Yes \\
\hline Quadratic control & No & No & No & No & Yes & No & No \\
\hline Predetermined var. & No & No & No & No & No & Yes & No \\
\hline Day of birth as RV & No & No & No & No & No & No & Yes \\
\hline Weekday FE & No & No & No & No & No & No & Yes \\
\hline
\end{tabular}

Notes: Standard errors are clustered on week * election level. */**/*** significant at the $10 / 5 / 1$ percent level. $\mathrm{RV}=$ running variable. 
Table B 3. Heterogeneity: high school grade Social Studies

\begin{tabular}{|c|c|c|c|c|c|c|c|}
\hline Column: & $(1)$ & (2) & (3) & (4) & (5) & (6) & $(7)$ \\
\hline Bandwidth: & {$[-6,7]$} & {$[-5,6]$} & {$[-4,5]$} & {$[-3,4]$} & {$[-6,7]$} & {$[-6,7]$} & {$[-6,7]$} \\
\hline \multicolumn{8}{|l|}{ Panel A: Males } \\
\hline \multirow[t]{2}{*}{ Voting right } & -0.0090 & 0.0009 & 0.0017 & 0.0174 & 0.0228 & -0.0003 & -0.0090 \\
\hline & $(0.0158)$ & $(0.0173)$ & $(0.0181)$ & $(0.0199)$ & $(0.0242)$ & $(0.0128)$ & (0.0169) \\
\hline Mean of dep. & -0.143 & -0.142 & -0.145 & -0.142 & -0.143 & -0.143 & -0.143 \\
\hline Observations & 54,735 & 47,840 & 40,308 & 32,524 & 54,735 & 54,735 & 54,735 \\
\hline \multicolumn{8}{|l|}{ Panel B: Females } \\
\hline \multirow[t]{2}{*}{ Voting right } & -0.0168 & -0.0173 & -0.0146 & -0.0112 & -0.0212 & -0.0173 & -0.0183 \\
\hline & $(0.0141)$ & $(0.0147)$ & $(0.0162)$ & $(0.0184)$ & $(0.0206)$ & $(0.0122)$ & $(0.0153)$ \\
\hline Mean of dep. & 0.0987 & 0.0972 & 0.0972 & 0.0981 & 0.0987 & 0.0987 & 0.0987 \\
\hline Observations & 61,978 & 54,115 & 45,360 & 36,616 & 61,978 & 61,978 & 61,978 \\
\hline \multicolumn{8}{|c|}{ Panel C: Individuals with at least one highly educated parent } \\
\hline \multirow[t]{2}{*}{ Voting right } & -0.0168 & -0.0189 & -0.0060 & -0.0188 & -0.0135 & -0.0251 & -0.0148 \\
\hline & $(0.0188)$ & $(0.0202)$ & $(0.0223)$ & $(0.0269)$ & $(0.0316)$ & $(0.0157)$ & $(0.0226)$ \\
\hline Mean of dep. & 0.366 & 0.368 & 0.363 & 0.366 & 0.366 & 0.366 & 0.366 \\
\hline Observations & 29,365 & 25,630 & 21,528 & 17,366 & 29,365 & 29,365 & 29,365 \\
\hline \multicolumn{8}{|c|}{ Panel D: Individuals with no highly educated parent } \\
\hline \multirow[t]{2}{*}{ Voting right } & -0.0114 & -0.0058 & -0.0044 & 0.0145 & 0.0098 & -0.0055 & -0.0131 \\
\hline & $(0.0113)$ & $(0.0118)$ & $(0.0121)$ & $(0.0139)$ & $(0.0160)$ & $(0.0094)$ & $(0.0121)$ \\
\hline Mean of dep. & -0.143 & -0.144 & -0.144 & -0.143 & -0.143 & -0.143 & -0.143 \\
\hline Observations & 87,348 & 76,325 & 64,140 & 51,774 & 87,348 & 87,348 & 87,348 \\
\hline Linear control & Yes & Yes & Yes & Yes & Yes & Yes & Yes \\
\hline Election FE & Yes & Yes & Yes & Yes & Yes & Yes & Yes \\
\hline Quadratic control & No & No & No & No & Yes & No & No \\
\hline Predetermined var. & No & No & No & No & No & Yes & No \\
\hline Day of birth as RV & No & No & No & No & No & No & Yes \\
\hline Weekday FE & No & No & No & No & No & No & Yes \\
\hline
\end{tabular}

Notes: Standard errors are clustered on week * election level. $* / * * / * * *$ significant at the $10 / 5 / 1$ percent level. $\mathrm{RV}=$ running variable. 
Table B 4. Heterogeneity: SweSAT scores

\begin{tabular}{|c|c|c|c|c|c|c|c|}
\hline Column: & $(1)$ & (2) & (3) & (4) & (5) & (6) & (7) \\
\hline Bandwidth: & {$[-6,7]$} & {$[-5,6]$} & {$[-4,5]$} & {$[-3,4]$} & {$[-6,7]$} & {$[-6,7]$} & {$[-6,7]$} \\
\hline \multicolumn{8}{|l|}{ Panel A: Males } \\
\hline \multirow[t]{2}{*}{ Voting right } & -0.0711 & -0.0676 & -0.0404 & -0.0277 & -0.0041 & $-0.0761^{*}$ & -0.0705 \\
\hline & $(0.0477)$ & $(0.0512)$ & $(0.0519)$ & $(0.0598)$ & $(0.0641)$ & $(0.0429)$ & $(0.0526)$ \\
\hline Mean of dep. & -0.0159 & -0.0163 & -0.0110 & -0.0234 & -0.0159 & -0.0159 & -0.0159 \\
\hline Observations & 6,435 & 5,637 & 4,745 & 3,774 & 6,435 & 6,435 & 6,435 \\
\hline \multicolumn{8}{|l|}{ Panel B: Females } \\
\hline \multirow[t]{2}{*}{ Voting right } & -0.0052 & 0.0154 & $0.0588^{*}$ & $0.0604^{*}$ & $0.0919 * \star$ & -0.0274 & 0.0018 \\
\hline & $(0.0294)$ & $(0.0320)$ & $(0.0306)$ & $(0.0340)$ & $(0.0381)$ & $(0.0277)$ & $(0.0425)$ \\
\hline Mean of dep. & -0.432 & -0.428 & -0.423 & -0.426 & -0.432 & -0.432 & -0.432 \\
\hline Observations & 8,103 & 7,048 & 5,912 & 4,706 & 8,103 & 8,103 & 8,103 \\
\hline \multicolumn{8}{|c|}{ Panel C: Individuals with at least one highly educated parent } \\
\hline \multirow[t]{2}{*}{ Voting right } & -0.0571 & -0.0439 & -0.0135 & $-0.0856^{*}$ & -0.0197 & $-0.0805^{\star \star}$ & -0.0431 \\
\hline & $(0.0372)$ & $(0.0442)$ & $(0.0436)$ & $(0.0451)$ & $(0.0567)$ & $(0.0339)$ & $(0.0490)$ \\
\hline Mean of dep. & -0.0409 & -0.0338 & -0.0212 & -0.0240 & -0.0409 & -0.0409 & -0.0409 \\
\hline Observations & 5,432 & 4,727 & 3,934 & 3,140 & 5,432 & 5,432 & 5,432 \\
\hline \multicolumn{8}{|c|}{ Panel D: Individuals with no highly educated parent } \\
\hline \multirow[t]{2}{*}{ Voting right } & -0.0162 & -0.0119 & 0.0209 & 0.0672 & 0.0634 & -0.0353 & -0.0167 \\
\hline & $(0.0329)$ & $(0.0383)$ & $(0.0370)$ & $(0.0458)$ & $(0.0524)$ & $(0.0246)$ & $(0.0416)$ \\
\hline Mean of dep. & -0.371 & -0.371 & -0.367 & -0.378 & -0.371 & -0.371 & -0.371 \\
\hline Observations & 9,106 & 7,958 & 6,723 & 5,340 & 9,106 & 9,106 & 9,106 \\
\hline Linear control & Yes & Yes & Yes & Yes & Yes & Yes & Yes \\
\hline Election FE & Yes & Yes & Yes & Yes & Yes & Yes & Yes \\
\hline Quadratic control & No & No & No & No & Yes & No & No \\
\hline Predetermined var. & No & No & No & No & No & Yes & No \\
\hline Day of birth as RV & No & No & No & No & No & No & Yes \\
\hline Weekday FE & No & No & No & No & No & No & Yes \\
\hline
\end{tabular}

Notes: Standard errors are clustered on week * election level. $* / * * / * * *$ significant at the $10 / 5 / 1$ percent level. $\mathrm{RV}=$ running variable. 


\section{Publication series published by IFAU - latest issues}

\section{Rapporter/Reports}

2016:1 Engdahl Mattias and Anders Forslund "En förlorad generation? Om ungas etablering på arbetsmarknaden"

2016:2 Bastani Spencer, Ylva Moberg and Håkan Selin ”Hur känslig är gifta kvinnors sysselsättning för förändringar i skatte- och bidragssystemet?”

2016:3 Lundin Martin, Oskar Nordström Skans and Pär Zetterberg ”Kåren och karriären: Studentpolitiken som språngbräda”

2016:4 Brommesson Douglas, Gissur Erlingsson, Johan Karlsson Schaffer, Jörgen Ödalen and Mattias Fogelgren "Att möta den högre utbildningens utmaningar"

2016:5 Egebark Johan "Effekter av skatter på ungas egenföretagande”

2016:6 Mannelqivst Ruth, Berndt Karlsson and Bengt Järvholm ”Arbete och arbetsmarknad i sjukförsäkringen”

2016:7 Rosenqvist Olof "Rösträtt och ungdomars kunskap om politik”

\section{Working papers}

2016:1 Bastani Spencer, Ylva Moberg and Håkan Selin "Estimating participation responses using transfer program reform"

2016:2 Lundin Martin, Oskar Nordström Skans and Pär Zetterberg "Leadership experiences, labor market entry,and early career trajectories"

2016:3 van den Berg Gerard J., Lena Janys, Enno Mammen and Jens P. Nielsen ”A general semiparametric approach to inference with marker-dependent hazard rate models"

2016:4 Egebark Johan "Effects of taxes on youth self-employment and income"

2016:5 Holmlund Helena "Education and equality of opportunity: what have we learned from educational reforms?”

2016:6 Rosenqvist Olof "Rising to the occasion? Youth political knowledge and the voting age"

\section{Dissertation series}

2015:1 Egebark Johan "Taxes, nudges and conformity. Essays in labor and behavioral economics"

2015:2 Blind Ina "Essays on urban economics" 